\title{
Fracking in Indian Country: The Federal Trust Relationship, Tribal Sovereignty, and the Beneficial Use of Produced Water
}

\author{
Heather Whitney-Williams \& Hillary M. Hoffmann†
}

Potentially toxic wastewater discharges from hydraulic fracturing-known as "produced water"-are not subject to RCRA's or the CWA's permitting requirements. This is because the EPA has categorized produced water as a "special waste" when put to "beneficial uses" in arid regions. Some chemical components in produced water, however, are patented trade secrets that may prove injurious to human health.

This Article addresses the issue of produced water as it relates to Native American tribal lands, where fracking activity is increasingly common. Despite their status as sovereign nations, Native American tribes neither have the authority to impose their own produced water permitting standards under RCRA, nor the ability to meet financially burdensome standards in order to regulate water quality under the CWA. Together, these regulatory exemptions and unrealistic standards form a "livestock loophole" that allows untreated produced water disposal onto Native American lands.

This Article, at the nexus of environmental law and Indian law, argues that tribes have an important and distinct role in both accepting or declining produced water discharges on tribal lands, and in setting their own water quality standards under the CWA. This Article then makes recommendations consistent with such an account of tribal sovereignty and the federal government's responsibility under the Federal Trust Doctrine.

Introduction. 452

I. Theoretical Background: Existing Scholarship Surrounding Mineral

Development on Native Lands

II. Fracking and the Adverse Health Effects of Produced Water.

III. Legal Components of the Produced Water "Livestock Loophole"

A. RCRA's E\&P Exemption for "Special Wastes".

$B$. The Clean Water Act's Livestock and Wildlife Subcategory.

C. The Rationale for, and Results of, the Livestock Loophole.

IV. The Wind River Nations and The Federal Government.

V. The Federal Trust Doctrine, RCRA, and the CWA

A. Background of the Federal Trust Doctrine

B. The Modern Federal Trust Doctrine. 
C. The EPA's Current Policies Regarding Its Federal Trust Responsibilities

$D$. The Federal Trust and the Livestock Loophole Under RCRA

E. The Federal Trust and the CWA's Livestock Loophole

$F$. Trade Secrets and the Federal Trust

VI. Moving Forward: Recommendations on How to Eliminate the

Livestock Loophole from Existing Laws

A. The EPA Should Revise RCRA's Exempt Status Trigger to Include Produced Water

$B$. The CWA's Livestock and Wildlife Subcategory Should Exclude Produced Water

C. The Federal Government Should Set Effluent Limits for Produced Water Contents for Non-TAS Tribes.

D. If the EPA Continues to Administer the CWA in Indian Country, Effective Monitoring, Inspections, and Scientific Studies Must Be Required.

E. The CWA's Spill Prevention, Control, and Countermeasure (SPCC) Rule Should be Enforced to Emphasize Tribal Protections

$F$. The Beneficial Use Requirement Must Be Revised to Reflect Federal or Tribal Control

G. Trade Secrets Protections Preventing Disclosure of Produced Water Content Must Be Eliminated in the Interest of Native Health.

H. The EPA's Role as Both Trustee and Regulator Presents a Conflict of Interest, so Another Agency Should Assume the Role of Trustee.

Conclusion

Introduction

"[T]he mere passage of time has not eroded the rights guaranteed by a solemn treaty that both sides pledged on their honor to uphold."1

The current legal regime surrounding wastewater discharges generated by hydraulic fracturing, otherwise known as "produced water," in Indian Country is

$\dagger \quad$ Heather Whitney-Williams, J.D., LL.M., specializes in water quality protection, endangered species protection, and environmental justice issues. She would like to thank Hillary Hoffmann for the invitation to co-author this article. Hillary M. Hoffmann is a Professor of Law at Vermont Law School. She thanks John Echeverria for his comments on an earlier version of this Article and Heather Whitney-Williams for her dedication to this Article and to the important issues it addresses.

1. State v. Tinno, 497 P.2d 1386, 1393 (Idaho 1972). 
seriously flawed. ${ }^{2}$ Produced water discharges are a hazardous by-product of hydraulic fracturing operations, and federal environmental laws currently exempt operators in Indian Country from disclosing many of the chemicals used in produced water, as well as their associated health and safety risks. ${ }^{3}$ Tribal and external oil and gas operations are exploiting a loophole in federal law and the western water rights regime that allows them to classify produced water discharges on tribal lands as having "beneficial uses," thereby exempting the discharges from pollution restrictions. Tribes are often willing participants in oil and gas exploration and production on their lands because of the economic benefits these operations produce for the tribe. Further, because of their sovereign status, tribes have the authority to accept wastewater discharges for their members, and some tribes do accept produced water for tribal livestock, based on an understanding that the federal government will monitor the integrity of the wells and pits containing the discharged fluids. ${ }^{4}$ Other tribes have adopted a more conservative approach, based on fears that the undisclosed contents of produced water are potentially hazardous to human health and to the tribal environment. $^{5}$

The Wind River Reservation, which made national news in 2012 because oil and gas companies were discharging water directly onto tribal pastures, ${ }^{6}$ provides a case study illustrating the potential harms from produced water discharges, particularly in Indian Country. ${ }^{7}$ The images captured by a visiting reporter on the Wind River Reservation showed "foam" and "sheen" on standing pools of black water while cattle grazed nearby. ${ }^{8}$ The reporter was warned to step away from the discharge points and told that she might experience "respiratory distress or death from hydrogen sulfide fumes." According to tribal officials, these produced water discharges, which are often highly toxic, have occurred "for several decades without attracting much interest." ${ }^{10}$ At times, Wind River

2. Resource Conservation and Recovery Act, 42 U.S.C. $\$ \$ 6901-6908$ a (2012); Clean Water Act, 33 U.S.C. $\$ \$ 1251-1387$ (2012); C.E. CLARK \& J.A. VEIL, PRODUCED WATER VOLUMES AND MANAGEMENT PRACTICES IN THE UNITED STATES 11 (2009), http:/www.circleofblue.org/waternews/wpcontent/uploads/2010/09/ANL_EVS_R09_produced_water_volume_report_2437.pdf.

3. Kendall Güule, Produced Water, FrackWIRE (June 25, 2013), http://frackwire.com /produced-water. "Indian Country" is a term of art in federal law, which includes all reservation land, trust allotments, and dependent Indian communities. See 18 U.S.C. $\$ 1151$ (2012). This Article is limited to tribes that reside in Indian Country, which are "recognized" by the federal government. Although the federal trust obligation discussed in this Article arguably relates to unrecognized tribes, this issue is beyond the scope of this Article.

4. Elizabeth Shongren, Loophole Lets Toxic Oil Water Flow Over Indian Land, NAT'L PUB. Radio (Nov. 15, 2012, 3:03 PM), http://www.npr.org/2012/11/15/164688735/loophole-lets-toxicoil-water-flow-over-indian-land; Talli Nauman, Tribes Urged to Ban Fracking on Reservations, NATIVE SUN NEwS (Aug. 12, 2014), http://www.indianz.com/News/2014/014717.asp.

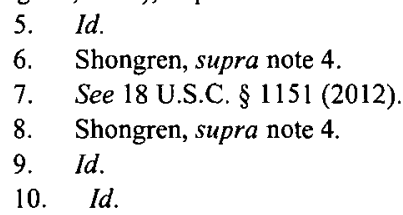


tribal environmental officials have tested water near the discharge sites, and on one occasion, they reported water temperatures exceeding 125 degrees Fahrenheit, toxic levels of various chemicals, and "streambeds splotched with black ooze, white crystals, and purple growths." "11

The Wind River Reservation's history helps to explain how the legal landscape evolved to allow produced water discharges throughout Indian Country. Today, this landscape includes a statutory and regulatory framework under two major environmental laws, the Resource Conservation and Recovery Act (RCRA) ${ }^{12}$ and the Clean Water Act (CWA). ${ }^{13}$ As this Article will show, several statutory and regulatory exemptions under RCRA and the CWA form a "livestock loophole" that allows untreated produced water disposal in Indian Country. In addition, the recently promulgated Bureau of Land Management (BLM) fracking rule does nothing to close this loophole.

Part I situates this Article in the existing literature and presents an overview of the legal issues surrounding mineral development on tribal lands. In Part II, this Article describes the fracking process, how produced water is generated, and the toxins known to occur in produced water discharges. Part III discusses the legal components of the livestock loophole, including RCRA, the CWA, and the regulations under each statute that allow produced water discharges on native lands and in native waters. Part IV discusses the Wind River tribes' history, including various treaty negotiations with the federal government and the concurrent development of the federal trust responsibility to these tribes. Part V discusses the Federal Trust Doctrine and relevant provisions of RCRA and the CWA, as well as trade secrets laws, which undermine the effective implementation of RCRA and the CWA. Part VI discusses necessary changes to RCRA and the CWA regulatory structures to eliminate the livestock loophole and to curb unregulated produced water discharges. The Conclusion encourages federal officials to implement the suggestions from Part VI to improve water quality, human health, and the health of wildlife and domestic livestock throughout Indian Country.

\section{Theoretical Background: Existing Scholarship Surrounding Mineral \\ Development on Native Lands}

Scholars of Native American law have extensively analyzed environmental degradation from mineral development, the legal framework authorizing energy development, and toxic waste disposal in Indian Country. ${ }^{14}$ Generally, scholarly

\footnotetext{
11. Id.

12. 42 U.S.C. $\S \S 6901-6992 \mathrm{k}(2012)$.

13. 33 U.S.C. $\$ \S 1251-1387$ (2012).

14. E.g., Michael C. Blumm, Retracing the Discovery Doctrine: Aboriginal Title, Tribal Sovereignty, and Their Significance to Treaty-Making and Modern Natural Resources Policy in Indian Country, 28 VT. L. REV. 713 (2004); Elizabeth Ann Kronk Warner, Examining Tribal Environmental Law, 39 COLUM. J. ENVTL. L. 42, 75 (2014) (discussing Navajo Nation Tribal Code provisions governing air pollution, water quality, and waste disposal); Elizabeth Ann Kronk, Tribal Energy Resource Agreements:
} 
suggestions for tightening regulatory requirements and eliminating gaps similar to the livestock loophole fall into three categories: calls for new federal legislation, suggestions for strengthening tribal enforcement mechanisms, and calls for increased collaboration between tribes and the federal government, states, or private landowners. ${ }^{15}$ Some scholars, particularly in recent years, view an increased tribal role in environmental regulation-in the form of new or stronger tribal environmental ordinances and regulations-as a means of preventing the hazardous environmental externalities associated with mineral development on tribal lands. ${ }^{16}$ Others have suggested that states might play a role. ${ }^{17}$ Yet even their proponents acknowledge that these suggestions are not perfect solutions because not all tribes have the financial or organizational means to strengthen their environmental regulations, much less to enforce subsequent violations, and states possess very limited regulatory authority in Indian Country. ${ }^{18}$ Furthermore, additional congressional assistance to tribes is unlikely at this time, since Congress has been virtually stuck in political deadlock over the past several years. ${ }^{19}$

This Article takes a different, and new, approach to advocate for increased federal disclosure requirements surrounding produced water contents and more stringent enforcement of existing laws governing produced water disposal in Indian Country. The theoretical foundation for this approach is not new, and in fact lies in one of the oldest doctrines in Native American Law-the Federal Trust Doctrine. The Federal Trust Doctrine provides an effective resolution that both protects tribal health and the tribal environment, while respecting tribal sovereignty, because it does not infringe upon tribes' legal ability to accept or decline produced water discharges. It simply proposes that, if tribes choose to accept produced water, the federal government must provide full disclosure about the nature of the substances that the tribes are accepting. The doctrine also requires the federal government to adhere to its own statutes and regulations regarding monitoring and enforcement.

Unlike other scholarship in this field, this Article does not suggest that an increased federal role is preferred to that of an increased tribal role, and it places

The Unintended "Great Mischief for Indian Energy Development" and the Resulting Need for Reform, 29 PACE ENVTL. L. REV. 811 (2012).

15. See, e.g., Marissa Tripolsky, A New NEPA to Take a Bite out of Environmental Injustice, 23 B.U. PUB. INT'L L.J. 313 (2014); Heather J. Tanana \& John C. Ruple, Energy Development in Indian Country: Working Within the Realm of Indian Law and Moving Towards Collaboration, 32 UTAH ENVTL. L. REV. 1 (2012); Kevin Gover \& James B. Cooney, Cooperation Between Tribes and States in Protecting the Environment, 10 NAT. RESOURCES \& ENV'T 35 (1996).

16. See Jennifer Smith Haner, Tribal Solutions to On-Reservation Environmental Offenses: Jurisdictional Parameters, Cultural Considerations, and Recommendations, 19 AM. INDIAN L. REV. 105 (1994); Kronk Wamer, supra note 14, at 75.

17. See Gover \& Cooney, supra note 15 .

18. Haner, supra note 16, at 115 ; Kronk Warner, supra note 14, at 94.

19. Paul Kane, 113th Congress, Going Down in History for its Inaction, Has a Critical December To-Do List, WASH. POST (Dec. 1, 2013), http://www.washingtonpost.com/politics/113thcongress-going-down-in-history-for-its-inaction-has-a-critical-december-to-dolist/2013/12/01/cf2b4808-57a0-11 e3-8304-caf30787c0a9_story.html 
no value judgment on the "rightness" of the federal role in environmental enforcement. Rather, using the Federal Trust Doctrine, this Article proposes to empower tribes to eliminate or curtail produced water disposal on their lands, particularly when they lack the resources or political means to implement more stringent toxic disposal regulations or ordinances, based on access to better information about the contents of the produced water. Regardless of the extent to which an individual tribe regulates fracking, the federal government's uniform fulfillment of its trust responsibility is an important step in demonstrating respect for tribal sovereignty and supporting existing policies of self-determination through environmental protection. That is because, as stated above, tribes that decide to accept produced water cannot make fully informed decisions about potential impacts to members' health, and the health of tribal livestock and reservation wildlife, without access to complete information about the risks they are undertaking. Failing to provide this information, which is what the current legal regime allows, is a breach of the federal government's trust obligation to the tribes.

\section{Fracking and the Adverse Health Effects of Produced Water}

The lands in and around Indian Country contain vast mineral deposits, including large oil and gas deposits in subsurface shale formations called "plays," coal bed methane, and other porous formations..$^{20}$ Traditionally, the oil and gas industry lacked the technical expertise to extract these minerals from many locations because they were in tight, hard-to-reach places, but the advent of better horizontal drilling techniques has resulted in a dramatic surge in drilling in and near Indian Country throughout the United States. ${ }^{21}$ Hydraulic fracturing, or "fracking," which uses vertical and horizontal drilling techniques, is the preferred method of extracting subsurface oil and natural gas from shale plays and coal bed methane seams. ${ }^{22}$ Currently, there are over one million active oil and gas wells in the country. ${ }^{23}$ It is difficult to assess how many of those are fracked because states do not require disclosure of drilling techniques, but rough estimates place the number of fracked wells at about $700,000 .^{24}$

Produced water is water that has been injected into a well, together with proppants that aid in fracturing the subsurface formation, and then trapped in underground shale formations before returning to the surface during drilling

20. Oil and Gas Outlook in Indian Country, U.S. BUREAU OF INDIAN AFFAIRS 4, http:// www.bia.gov/cs/groups/xieed/documents/document/idc1-024535.pdf (last visited Aug. 26, 2015).

21. See id. at 4-5.

22. See Emily C. Powers, Fracking and Federalism: Support for an Adaptive Approach that Avoids the Tragedy of the Regulatory Commons, 19 J. L. \& POL'Y 913, 918-19 (2011).

23. Rachael Ehrenberg, The Facts Behind the Frack, SCI. NEws (Aug 24, 2012 10:37 AM), https://www.sciencenews.org/article/facts-behind-frack.

24. Matt Kelso, Over 1.I Million Active Oil and Gas Wells in the U.S., FraCTRACKER (Mar. 4, 2014), http://www.fractracker.org/2014/03/1-million-wells (noting that almost 700,000 of the 1.1 million wells might be fracked, but that publicly available data is unavailable to confirm or exclude them). 
operations. ${ }^{25}$ In other words, it is "any water that is present in a reservoir with the hydrocarbon resource and is produced to the surface with the crude oil or natural gas." ${ }^{26}$ Produced water is essentially a mixture of surface water, proppant chemicals, and naturally occurring underground minerals and water that is generated during the fracking process when an oil or gas exploration well pumps fluids at high pressure into geologic formations. ${ }^{27}$ "When [that] pressure exceeds the rock strength, the fluids open or enlarge fractures that can extend several hundred feet away from the well." 28 The fractures must be stabilized using the proppant fluid, which is "pumped into the fractures to keep them from closing when the pumping pressure is released." 29 "After [the] fracturing is completed, the internal pressure of the geologic formation cause[s] the injected fracturing fluids to rise to the surface." ${ }^{\text {"30 }}$ A typical fracked well uses between four and six million gallons of water per fracture. ${ }^{31}$

In general, proppants are used in every fracking operation. ${ }^{32}$ The chemical combinations vary depending on the rock formation into which they are injected, but current estimates place the number of chemicals used in fracking operations at more than six hundred. ${ }^{33}$ These can include radioactive material, mercury, arsenic, and other heavy metals. ${ }^{34}$ The quality of produced water varies from one well site to the next, depending on the production zone depth and the formation's geochemistry. ${ }^{35}$ High concentrations of benzene, naphthalene, toluene, bromodichloromethane, pentachlorophenol, and phenanthrene have been found in fracking disposal areas, as well as inorganics such as arsenic, sulfur, antimony,

25. See JoHn A. Veil et al., A White Paper Describing Produced Water From Production of Crude Oll, Natural Gas, and CoAl Bed Methane 1 (2004), http:// www.netl.doe.gov/publications/oil_pubs/prodwaterpaper.pdf; U.S. ENVTL, PROTECTION AGENCY, COALBED METHANE EXTRACTION: DETAILED STUDY REPORT 4-2 (2004), http://www.epa.gov/ogwdw /uic/pdfs/cbmstudy_attach_uic_ch04_hyd_frac_fluids.pdf.

26. Id.

27. See generally Hydraulic Fracturing Background Information, U.S. ENVTL. PROTECTION AGENCY, http://water.epa.gov/type/groundwater/uic/class2/hydraulicfracturing/wells hydrowhat.cfm (last visited Dec. 16, 2014).

28. Id.

29. Id.

30. Id.

31. Bryan Walsh, Fracking for Natural Gas May Help Us Save Water, TiME ECOCENTRIC (Dec. 23, 2013), http://science.time.com/2013/12/23/fracking-for-natural-gas-isnt-so-waterwasteful.

32. What Chemicals Are Used, FRACFOcUS, https://fracfocus.org/chemical-use/whatchemicals-are-used (last accessed Aug. 26, 2015).

33. Lberlekamp, EPA to Allow Consumption of Toxic Fracking Wastewater by Wildlife and Livestock, ECOWATCH (July 11,2013, 5: $18 \mathrm{PM}$ ), http://ecowatch.com/2013/epa-fracking-wastewater -agriculture.

34. Environmental Impacts Associated with Hydraulic Fracturing, THE NETWORK FOR PUBLIC HEALTH LAw, https://www.networkforphl.org/_asset/w74j2w/ (last accessed Aug. 26, 2015).

35. Avner Vengosh, et al., The Effects of Shale Gas Exploration and Hydraulic Fracturing On the Quality of Water Resources in the United States, PROCEDIA EARTH AND PLANETARY SCIENCE 863-65 (2013), http://sites.biology.duke.edu/jackson/peps2013.pdf. 
barium, and naphthalene, and radionuclides such as radium, radon, and uranium. $^{36}$

Produced water can be highly toxic and potentially harmful to human health, as well as to the health of wildlife and domestic livestock. Many chemicals present in produced water have demonstrated adverse health effects. Over "75 percent of them affect the respiratory and gastrointestinal systems; 4050 percent impact the kidneys and the nervous, immune and cardiovascular systems; 37 percent act on the hormone system; and 25 percent are linked with cancer or mutations." 37 In various cases, cattle exposed to produced water have died, the most dramatic case being seventeen cows that died within an hour of ingesting toxic produced water, which was later found to have caused respiratory failure with a circulatory collapse in the animals. ${ }^{38}$ Pregnant cows directly exposed to produced water have given birth to stillborn calves, or calves with congenital defects and reproductive problems. ${ }^{39}$ Cattle that die in situ cannot be introduced into the food supply, but those that have ingested produced water and survive can. ${ }^{40}$

Common forms of exposure to produced water for livestock and wildlife are wells, springs, ponds, creeks, impoundments (open pits), and spills. ${ }^{41}$ In one inadvertent case study, a herd of sixty cattle drank regularly from a creek containing produced water. ${ }^{42}$ The herd became separated, and one group of thirty-six was put in a pasture without access to the water, while the remaining herd drank from the contaminated creek. ${ }^{43}$ Of the latter group, " 21 died and 16 failed to produce calves the following spring." ${ }^{44}$ Of the group that did not have access to the creek, "no health problems were observed, and only one cow failed to breed." 45

Studies have shown that direct and indirect exposure to chemicals found in produced water can have severe consequences for humans as well, particularly for children. ${ }^{46}$ If produced water is stored in open impoundments, toxins can become airborne and drift over any nearby homes. ${ }^{47}$ Similarly, toxins from impoundments or underground injection wells can seep into groundwater supplies and contaminate nearby drinking water. ${ }^{48} \mathrm{~A}$ common offender is

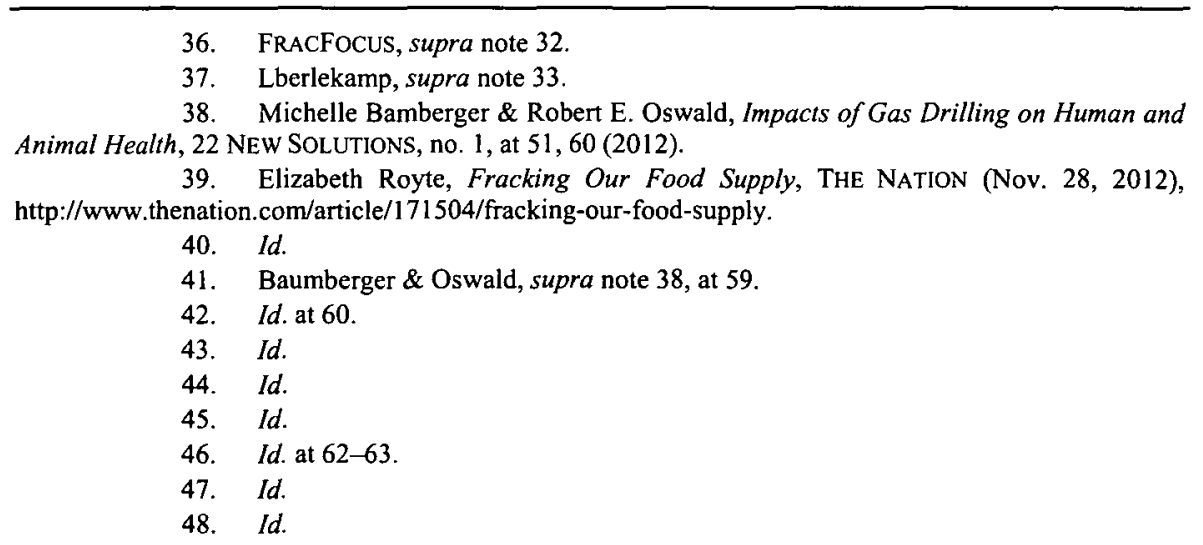


arsenic, a naturally occurring element in shale formations. ${ }^{49}$ During fracking operations, large quantities of arsenic can surface in produced water, which can then become airborne through the aeration process used by well operators at impoundments, or travel through groundwater into drinking water supplies. ${ }^{50}$ Exposure to arsenic in humans can cause "gastrointestinal effects as well as effects on the nervous system: short-term effects include headaches, weakness, and delirium, while long-term effects include peripheral neuropathy." 51

Contaminants in produced water can migrate into groundwater regardless of whether they are disposed of using deep well injection or in surface pits, as one EPA study in the small town of Pavillion, Wyoming, located on the Wind River Reservation, demonstrated. ${ }^{52}$ Both the EPA and the United States Geological Survey (USGS) have shown that the town's domestic water supply contains chemicals used in the fracking process. ${ }^{53}$ Residents in the area complained for years of "neurological impairment, loss of smell, and nerve pain they associate with exposure to pollutants." At one point, EPA officials warned residents to shut off their taps and blow fans to disperse fumes, for fear of "explosions" in their kitchen and bathroom faucets. ${ }^{55}$ Similar stories have emerged from other parts of the country as well, including states where fracking is prolific, such as Colorado, ${ }^{56}$ Texas, ${ }^{57}$ and Pennsylvania. ${ }^{58}$

\section{Id. \\ 50. Id. at 62 . \\ 51. Id. at 63 .}

52. Investigation of Groundwater Contamination Near Pavillion, Wyoming, U.S. ENVTL. ProteCTION AGENCY, (Dec. 2011), http://www2.epa.gov/sites/production/files/documents/EPA _ReportOnPavillion_Dec-8-2011.pdf; Wyoming Groundwater Again Tests Positive For Fracking-Related Chemicals on the Wind River Reservation, INDIAN COUNTRY TODAY (Sept. 27, 2012), http:// indiancountrytodaymedianetwork.com/2012/09/27/wyoming-groundwater-again-tests-positive-frackingrelated-chemicals-wind-river.

53. EPA Releases Results of Pavillion, Wyo. Water Well Testing, U.S. ENVTL. PROTECTION AGENCY (Sept. 1, 2010), http://yosemite.epa.gov/opa/admpress.nsf /20ed1 dfa 1751 192c8525735900400c30/lb6ae692cfeeab50852577920066afd4!OpenDocument.

54. Abrahm Lustgarten, EPA Finds Compound Used in Fracking in Wyoming Aquifer, ProPuBLICA (Nov. 10, 2011, 1:10 PM), http://www.propublica.org/article/epa-finds-fracking-compoundin-wyoming-aquifer.

55. Noel Brinkerhoff \& David Wallechinsky, Wyoming Town Warned to Use Fans While Showering to Avoid Chemical Explosions, ALLGov (Sept. 13, 2012), http://www.allgov.com /news/controversies/wyoming-town-warned-to-use-fans-while-showering-to-avoid-chemical-

explosions?news=841388; see also Abrahm Lustgarten, Feds Warn Residents Near Wyoming Gas Drilling Sites Not to Drink Their Water, PROPUBLICA (Sept. 1, 2010), http://www.propublica.org /article/feds-warn-residents-near-wyoming-gas-drilling-sites-not-to-drink-their-wate.

55. Pavillion Groundwater Investigation, U.S. ENVTL. Protection AGenCY http://www2.epa.gov/region8/pavillion (last updated Mar. 26, 2014),

56. Sandra Postel, Hormone-Disrupting Chemicals Linked to Fracking Found in Colorado River, NAT'L GEOGRAPHIC (Dec. 20, 2013), http://voices.nationalgeographic.com/2013/12/20 /hormone-disrupting-chemicals-linked-to-fracking-found-in-colorado-river/.

57. Reckless Endangerment While Fracking the Eagle Ford, EARTHWORKS, (Sept. 2013), http://www.earthworksaction.org/files/publications/FULL-RecklessEndangerment-sm.pdf.

58. Neela Banerjee, Natural Gas Production Contaminated Drinking Water in Texas, Study Finds, L.A. TIMES (Sept. 15, 2014, 6:57 PM), http://www.latimes.com/nation/nationnow/la-na-nngas-wells-drinking-water-contamination-20140915-story.html. 


\section{Legal Components of the Produced Water "Livestock Loophole"}

The discussion that follows will explore the legal landscape that has evolved to allow produced water discharges in Indian Country, using the Wind River Reservation's history to explain how such a system develops. Today, the federal components of that system include two major environmental laws: the Resource Conservation and Recovery Act ${ }^{59}$ (RCRA) and the Clean Water Act (CWA). ${ }^{60}$ The Department of Interior has authority to regulate these discharges under both statutes, and traditionally the EPA has assumed primary authority under RCRA and the CWA. ${ }^{61}$ The Bureau of Land Management (BLM) also regulates fracking in Indian Country, but its involvement is primarily limited to front-end issues like planning, siting, exploration, and drilling. ${ }^{62}$ The manner in which both agencies regulate produced water discharges will be discussed more fully in Part VI, below.

RCRA ordinarily prohibits toxic waste discharges, but Congress and the EPA have exempted produced water and drilling fluids ${ }^{63}$ from Subtitle C's "cradle to grave" hazardous waste requirements. ${ }^{64}$ Subtitle $\mathrm{C}$ is referred to in this manner because its provisions govern hazardous waste management from the moment waste is generated until the moment it is disposed of. Furthermore, despite the sovereign status of tribes, courts have held that they lack authority to impose permitting standards of their own because Congress did not delegate such authority to tribes in RCRA. ${ }^{65}$

EPA regulations, in turn, prohibit water-based discharges of the toxic chemicals contained in produced water, ${ }^{66}$ but allow produced water to be used

59. $\quad 42$ U.S.C. $\$ \S 6901-6992 \mathrm{k}(2012)$.

60. 33 U.S.C. $\$ \$ 1251-1387$ (2012). The Department of Interior also generally regulates fracking in Indian Country under the Indian Mineral Leasing Act, 25 U.S.C. $\$ \S 396 \mathrm{a}-396 \mathrm{~g}(2012)$; see also 25 C.F.R. pt. 211 (1993), the Indian Mineral Development Act, 25 U.S.C. $\S \S 2101-2108$ (2012), and other statutes, but those statutes primarily treat the "front-end" of oil and gas mining (planning, siting, exploration, and drilling). This Article focuses only on the "back-end" (disposal of fracking fluids, specifically).

61. Timothy O. Schimpf, Unleash RCRA! Letting Loose the Corrective Action Process of RCRA Can Change the World, 29 WM. \& MARY ENVTL. L. \& POL'Y REV. 481, 482 (2005).

62. The BLM regulations governing disposal of fracking fluids are minimal, and will be further discussed in Part VI, infra.

63. See EnVtl. Protection Agency, EXemption of OIl and Gas ExPloration and Production Wastes from federal Hazardous Waste Regulations 5 (2002), http://www.epa.gov/osw/nonhaz/industrial/special/oil/oil-gas.pdf [hereinafter OIL AND GAS EXEMPTION].

64. 42 U.S.C. $\S \S 6921-6939$ (b) (2012); 40 C.F.R. $\S \S 260.1-299$ (2015); Shell Oil v. EPA, 950 F.2d 741, 745 (D.C. Cir. 1991).

65. Backcountry Against Dumps v. EPA, 100 F.3d 147, 150 (D.C. Cir. 1996) (discussing RCRA's definition of Indian tribes as "municipalities" under 42 U.S.C. $\$ 6903(13)$, and holding that RCRA allowed only states to submit solid waste management plans to the EPA, thus delegating regulation authority to the EPA); see 42 U.S.C. $§ 6945$ (c) (allowing "states" to implement standards under RCRA).

66. Clean Water Act, 33 U.S.C. $\S \S 1252$ (a) (establishment of pollution control programs), 1342(a) (prohibiting discharge of pollutants without a permit); $\$ 1362(6)$ (defining pollutant as "dredged spoil, solid waste, incinerator residue, sewage, garbage, sewage sludge, munitions, chemical wastes, biological materials, radioactive materials, heat, wrecked or discarded equipment, rock, sand, 
for agriculture and wildlife west of the 98 th meridian, ${ }^{67}$ including in Indian Country. Together, these statutory and regulatory exemptions under RCRA and the CWA form a "livestock loophole," allowing untreated produced water disposal in Indian Country.

\section{A. RCRA's E\&P Exemption for "Special Wastes"}

In general, RCRA governs the "land disposal" of hazardous and solid waste throughout the United States. ${ }^{68}$ In Indian Country and elsewhere, the EPA administers RCRA, and the agency has promulgated regulations defining the characteristics of various forms of hazardous solid wastes and imposing standards governing their disposal. ${ }^{69}$ When RCRA was passed in 1976, Congress's overarching policy goal was to protect human health and the environment by banning all open dumping waste so that "wherever feasible, the generation of hazardous waste is to be reduced or eliminated as expeditiously as possible. Waste that is nevertheless generated should be treated, stored, or disposed of so as to minimize the present and future threat to human health and the environment." ${ }^{, 70}$

In RCRA, Congress defined "hazardous waste" as

a solid waste, or combination of solid wastes, which because of its quantity, concentration, or physical, chemical, or infectious characteristics may (A) cause, or significantly contribute to, an increase in mortality or an increase in serious, irreversible, or incapacitating reversible, illness; or (B) pose a substantial present or potential hazard to human health or the environment when improperly treated, stored, transported, or disposed of, or otherwise managed. ${ }^{71}$

The EPA's system of regulations governing disposal of solid waste under RCRA is "labyrinth-like." 72 To start, there are two categories of solid waste

cellar dirt and industrial, municipal, and agricultural waste"); 40 C.F.R. $\S 435.32$ ("[T]here shall be no discharge of waste water pollutants into navigable waters from any source associated with production, field exploration, drilling, well completion, or well treatment (i.e., produced water, drilling muds, drill cuttings, and produced sand).").

67. 40 C.F.R. $\$ 435.50$ (2014). These discharges must meet certain effluent standards set in 1980 under 40 C.F.R. $\$ 435.52$ (b) (2014). The CWA does not address the problems of salinity and alkalinity, which, for example, are not to exceed $2,000 \mathrm{mg} / \mathrm{L}$ and $\mathrm{pH}$ ranging from 5.5 to 8.5 for watering livestock according to the National Academy of Sciences. U.S. DEP'T OF THE INTERIOR, OIL AND GAS Produced WATER MGMT aNd BENEFicial USE IN THE W. UNITED States 27 (Sept. 2011), http://www.usbr.gov/research/AWT/reportpdfs/report157.pdf; see also WALLACE STEGNER, THE AMERICAN WEST AS LIVING SPACE 5 (1987) (describing the 98th meridian as the geographical line "reaching southward about a third of the way across the Dakotas, Nebraska, and Kansas, and then swerving more southwestward across Oklahoma and Texas").

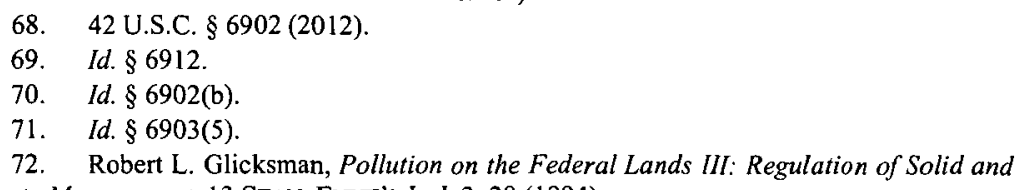
Hazardous Waste Management, 13 STAN. ENVT'L L. J. 3, 28 (1994). 
under RCRA, hazardous and nonhazardous. ${ }^{73}$ Hazardous waste is governed by Subtitle C of RCRA, and nonhazardous waste is governed by Subtitle D. ${ }^{74}$ The EPA originally proposed regulations under Subtitle $C$ to govern hazardous waste disposal in 1978, but the agency removed six categories of waste that it deemed "special wastes," which were considered to be lower in toxicity and thus subject to less stringent regulation. ${ }^{75}$ This category of so-called "nonhazardous wastes" includes Exploration and Production (E\&P) wastes, such as produced water. ${ }^{76}$ Shortly thereafter, the EPA promulgated the "Hazardous Waste Management System" 77 that established the cradle-to-grave hazardous waste management framework that is still used today. ${ }^{78}$

Until 1980, E\&P wastes were less stringently regulated under Subtitle C than other hazardous wastes, but they were still subject to various disposal requirements. ${ }^{79}$ This changed in 1980 , when Congress amended RCRA to exempt entire categories of special wastes through what are commonly referred to as the Bentsen and Bevill Amendments. ${ }^{80}$ The Bevill Amendment exempted "fossil fuel combustion waste ... and waste from the extraction, beneficiation, and processing of ores and minerals (including phosphate rock and overburden from uranium ore mining), which would otherwise fall under RCRA's disposal restrictions." ${ }^{81}$ According to the EPA, an E\&P waste can be classified as exempt from RCRA Subtitle $C$ regulations if it was "brought to the surface during oil and gas E\&P operations" or if it was "generated by contact with the oil and gas production stream during the removal of produced water or other contaminants from the product." ${ }^{12}$ The Bentsen Amendment, in turn, temporarily exempted "drilling fluids, produced waters, and other wastes associated with the exploration, development, and production of crude oil or natural gas," ${ }^{13}$ and required the EPA to conduct studies of the wastes' potential risk to human health and the environment, and the management status of the wastes by $1982 .{ }^{84}$

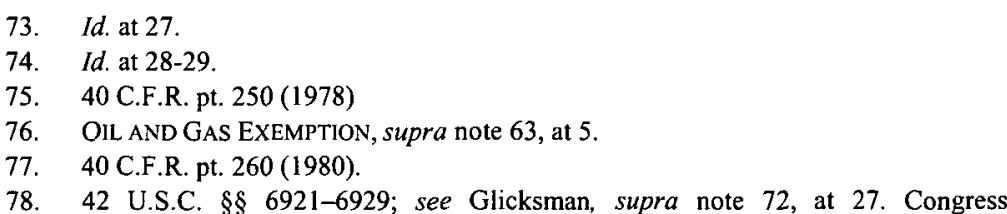
subsequently strengthened RCRA in the Federal Hazardous and Solid Waste Amendments (HSWA). See United Tech. Corp. v. EPA, 821 F.2d 714, 716 (D.C. Cir. 1987); Hazardous and Solid Waste Amendments Act, Pub. L. No. 98-616, 98 Stat. 3221 (1984). These amendments made "the reduction or elimination of hazardous waste generation at the source a priority of the RCRA hazardous waste program." Goals of RCRA, U.S. ENVTL. PROTECTION AGENCY, http://www.epa.gov/region2/waste/goals.htm (last visited Aug. 26, 2015).

79. Glicksman, supra note 72 , at 51 .

note 15 , at 33 .

80. 42 U.S.C. $\S 3001$ (b)(2)(A) \& $\$ 3001$ (b)(3)(A)(i-iii) (2012); Tanana \& Ruple, supra

81. 42 U.S.C. $\$ 6921(\mathrm{~b})(2)(\mathrm{A})(\mathrm{ii}),(3)(\mathrm{c})(1980)$.

82. OIL AND GAS EXEMPTION, supra note 63, at 8.

83. Tanana \& Ruple, supra note 15 , at 33-34 (citing 42 U.S.C. $\S 3001(b)(2)(A)$ (2006); 42 U.S.C. $\$ 6921$ (b)(2)(A) (2006)).

84. 42 U.S.C. $\S 6982(\mathrm{~m})(2)(2012)$. 
In 1988, six years after this deadline passed, the EPA extended the E\&P "special waste" exemption permanently to include drilling fluids and produced water. ${ }^{85}$ The 1988 regulation contradicted the EPA's initial claim that E\&P wastes were lower in toxicity than other wastes. Instead, the EPA stated that a waste's exemption is not determined by its toxicity but on "how the material was used or generated as waste." 86 The purpose behind this lack of subsequent action was to ensure that federal regulations would not "adversely affect the oil and gas industry." 87 Thus, E\&P special wastes, such as produced water, can be disposed of on land, and used as livestock water, regardless of their contents.

\section{B. The Clean Water Act's Livestock and Wildlife Subcategory}

The $\mathrm{CWA}^{88}$ is the predominant environmental law that regulates the disposal of toxic pollution into "the Nation's waters." 89 Congress's intent in passing the law was to "restore and maintain the chemical, physical, and biological integrity"90 of those waters by $1985 .{ }^{91}$ Needless to say, this deadline passed without the EPA having accomplished the statutory mandate.

At its inception, the CWA incorporated principles of environmental federalism, or a shared authority between the federal government and states, under which the EPA set federal guidelines, programs, and effluent limits, and states, territories, and authorized tribes administered and enforced them. ${ }^{92}$ The permitting program is called the National Pollutant Discharge Elimination System (NPDES), ${ }^{93}$ under which the EPA utilizes two standards of measurement

85. 40 C.F.R. $\S 261.4$ (b)(5) ("Drilling fluids, produced waters, and other wastes associated with the exploration, development, or production of crude oil, natural gas or geothermal energy.").

86. OIL AND GAS EXEMPTION, supra note 63, at 8.

87. Glicksman, supra note 72 , at 51-52.

88. 33 U.S.C. $\$ \$ 1251-1388$ (2012).

89. Id. $\S 1251$ (a); Clean Water Rule: Definition of "Waters of the United States," 80 Fed. Reg. 37,054 (June 29, 2015) (to be codified at 40 C.F.R. pts. 110, 112, 116, 117, 122, 230, 232, 300, $302,401)$.

90. 33 U.S.C. $\S 1251$ (a) (2012).

91. 33 U.S.C. $\$ 1251$ (a)(2) (2012). There have been efforts to achieve these goals, but pushback from industry and other stakeholders have limited successes. The legislative outlook is tenuous due to efforts in Congress to repeal the federal oversight section of the CWA, which was put in place to ensure states complied with anti-pollution efforts. Republican members of the House of Representatives introduced the Clean Water Cooperative Federalism Act of 2011, which is now languishing on the legislative calendar. See Bill Summary \& Status, LIBRARY OF CONGRESS, http://thomas.loc.gov/cgibin/bdquery/z?d112:HR02018:@@@S. For analysis of the bill by former New York Congressman Sherwood Boehlert, see Sherwood Boehlert, H.R. 2018 Would Undermine the Clean Water Act and Should Provoke Backlash. HUFF POST GREEN, July 13, 2011 , http://www.huffingtonpost.com/sherwoodboehlert/hr-2018-clean-water-act_b_897272.html.

92. 33 U.S.C. $\$ 1377(\mathrm{~h})(2)(2012)$; See generally The Clean Water Act: Protecting and Restoring the Nation's Waters, UNITED STATES ENVIRONMENTAL PROTECTION AGENCY, http:// water.epa.gov/action/cleanwater40/cwa 101.cfm (last updated Sept. 20, 2012).

93. National Pollutant Discharge Elimination System, ENVTL. PROTECTION AGENCY, http://water.epa.gov/polwaste/npdes/ (last accessed Sept. 11, 2015). 
to regulate pollution discharges, or effluents, into navigable waters ${ }^{94}$ : the technology-based standard and the water quality based standard. ${ }^{95}$ The technology-based standard sets a nation-wide minimum level of treatment of pollutants and requires the EPA to incorporate the best available technology (BAT) to reduce pollution into waterbodies. ${ }^{96}$ The water quality-based standard requires permit writers to consider the impact of every discharge into navigable waters and to incorporate effluent limits that are more stringent than the technology standard. ${ }^{97}$

Produced water discharges in the arid western United States are given a special section in the CWA in order to accommodate the ranching, agriculture, and wildlife sectors: the "Agricultural and Wildlife Water Use Subcategory." 98 Produced water use for such living organisms "[i]s intended as a relatively restrictive subcategorization based on the unique factors of prior usage in the region, arid conditions and the existence of low salinity, potable water." ${ }^{.99}$ In other words, produced water is considered beneficial to agriculture, livestock, and wildlife of the arid west, regardless of its contents, since water is in short supply.

Under the CWA's regulations, the beneficial use of produced water is authorized if it is of "good enough quality"100 for "wildlife or livestock watering or other agricultural uses" and if "the produced water is actually put to ... use during periods of discharge." ${ }^{101}$ This reuse of water policy reflects aspects of the "prior appropriation doctrine," 102 the foundational principle of western water

94. Ann E. Tweedy, Using Plenary Power as a Sword: Tribal Civil Regulatory Jurisdiction Under the Clean Water Act, 35 ENVTL. L. 471, 474 (2005).

95. Oliver A. Houck, Clean Water Act and Related Programs, AMER. L. INST.-A.B.A. CONTINUING LEGAL EDUC. (Feb. 12, 1997).

96. U.S. ENVTL. PROTECTION AGENCY, Water Quality and Technology-Based Permitting, http://water.epa.gov/polwaste/npdes/basics/Water-Quality-and-Technology-BasedPermitting.cfm (last updated Feb. 26, 2015).

97. Id.

98. 40 C.F.R pt. 435 subpt. E (2014)

99. 4 Fed. Reg. 22,069, 22,072 (Apr. 13, 1979); 40 C.F.R. pt. 435 (1979).

100. 40 C.F.R. $\$ 435.51$ (c) (2015).

101. 40 C.F.R. $\$ 435.51$ (c) (2015). The use of produced water "during periods of discharge" satisfies the Beneficial Use requirement under the prior appropriation doctrine.

102. See Irwin v. Phillips, 5 Cal. 140 (1855) (discussing whether a miner could divert a stream for mining operations and maintain that right, and holding he could if he had priority and used the diversion for a "high and legitimate purpose"); see Coffin v. Left Hand Ditch Co., 6 Colo. 447 (1882) ("[T]he first appropriator of water from a natural stream for a beneficial purpose has . . a prior right thereto to the extent of such appropriation."). In addition to livestock and wildlife watering, beneficial uses of produced water include irrigation, rangeland restoration, industrial uses, and streamflow augmentation. Katie Guerra et al., Oil and Gas Produced Water Management and Beneficial Use in the Western United States, U.S. DEP'T OF THE INTERIOR BUREAU OF RECLAMATION 1, 26-37 (Sept. 2011), https://www.usbr.gov/research/AWT/reportpdfs/report157.pdf. See generally Samuel C. Wiel, What is Beneficial Use of Water, 3 CAL. L. REV. 460, 460-75 (1915). See also The Wind River Tribal Water Code ch. 1, $\S E$, http://www.epa.gov/safewater/sourcewater/pubs/techguide_ord_wy_windriver_watercode.pdf (last accessed Sept. 17, 2015). 
law, ${ }^{103}$ which requires that every water right must be used in a beneficial manner in order to obtain and retain a superior appropriative water right. ${ }^{104}$ Under the prior appropriation system, beneficial use cannot include any element of waste ${ }^{105}$ and cannot be unreasonable considering alternative uses of water. ${ }^{106}$ There is at least one, albeit minimal, restriction on disposal of pollutants under the Agriculture and Wildlife Water Use Subcategory Rule: the produced water must not exceed the daily maximum effluent limit for oil and grease. ${ }^{107}$ Otherwise, the rule is vague enough to allow untreated produced water to be discharged directly into stock ponds and other bodies of water.

Beyond effluent limits, the EPA has not issued guidance on what constitutes "good enough" water quality for wildlife and livestock; nor has it put in place additional pollutant limitations or addressed the need to study whether more stringent regulations are required. ${ }^{108}$ According to EPA staff, the reason for this inaction is because some produced water is "high quality," and because the cost of injecting water underground might discourage beneficial use of produced water. ${ }^{109}$ As a result, because EPA believes that treatment of produced water is too expensive, oil and gas companies are permitted to discharge such water for wildlife and agricultural use, whether or not it is safe for consumption.

To summarize, RCRA's exemption of produced water from classification as hazardous waste and the use of produced water under the CWA's beneficial use doctrine (including the EPA's failure to define "good enough quality") combine to create the "livestock loophole" that allows oil and gas companies to dispose of production fluids in the arid west. Furthermore, because the livestock loophole does not even define health-based parameters for wildlife, livestock,

103. This is also known as the "Colorado Doctrine," from the case Colorado $v$. Wyoming, 259 U.S. 419 (1922), where the Court upheld prior appropriation as a superior water right. See also Coffin v. Left Hand Ditch Co., 6 Colo. 443 (1882).

104. Norman K. Johnson \& Charles T. DuMars, A Survey of the Evolution of Western Water Law in Response to Changing Economic and Public Interest Demands, 29 NAT. RESOURCES J. 347, 350 (1989).

105. State ex rel. Erickson v, McLean, 308 P.2d 983, 987 (N.M. 1957) (finding that discharge onto the ground from a leaky casing, lack of effective valve to control flow, and lack of a constructed irrigation system without constant supervision of user for more than four consecutive years, was not a beneficial use).

106. Vineyard Land \& Stock Co. v. Twin Falls Salmon River Land \& Water Co., 245 F. 9, 22-24 (9th Cir. 1917) (finding that the application of appropriated water for native grasses not a beneficial use).

107. 40 C.F.R. $\S 435.52$ (2014) ("Any existing point source . . . shall achieve the following effluent limitations . . . by the application of the best practicable control technology currently available (BPT) . . . Produced water discharges shall not exceed the following daily maximum limitation: $35[\mathrm{mg} / \mathrm{l}]$ of Oil and Grease.").

108. EPA has published a series of voluntary measures that generators can take to dispose of produced water safely, but as yet, the agency has published no rule requiring that generators undertake any of those measures. See Proper Management of Oil and Gas Exploration and Production Waste, U.S. ENVTL. PROTECTION AGENCY, http://www.epa.gov/epawaste/nonhaz/industrial/special/oil /hydrofrac.htm.

109. Unconventional Oil and Gas Development: Key Environmental and Public Health Requirements, Gov'T ACCOUNTABILITY OFFICE. 105 (Sept. 2012), http://www.gao.gov/assets/650 1647782.pdf. 
and human consumption of produced water, discharges are exempt from the stringent regulations that apply to other hazardous wastes.

\section{The Rationale for, and Results of, the Livestock Loophole}

As noted above, federal agencies consider produced water used for animal and human consumption as a beneficial use, since water is such a scarce resource west of the 98th meridian. ${ }^{110}$ Although reusing water in the arid west is a legitimate goal, the livestock loophole, in practice, primarily serves to accommodate the pollution disposal industry and oil and gas operators, and promotes environmentally unsafe waste management. For example, in western states, the BLM, which is the agency that regulates oil and gas drilling, as well as the disposal and storage of produced water on federal and Tribal lands, ${ }^{11}$ allows produced water to be re-used for several purposes, including irrigation, ${ }^{112}$ stream flow augmentation, ${ }^{113}$ and rangeland restoration (also known as landfarming or land application). ${ }^{114}$ Other disposal methods sanctioned by federal agencies include the use of open pits, ${ }^{115}$ underground injection, ${ }^{116}$ and offsite trucking. ${ }^{117}$

There are several methods of produced water disposal authorized under current federal law. The most popular method of disposal of produced water is underground injection due to its cost-effectiveness-reported as "between $\$ 0.30$ / bbl and $\$ 10.00 / \mathrm{bbl}$. In most cases, costs are less than $\$ 1.00 / \mathrm{bbl} . " 118$ The threat of liability for mistakes in surface water treatment also makes this method preferable, but it is not always feasible when the subsurface geologic formation

110. U.S. DEP'T OF INTERIOR, supra note 67, at 1, 7; see also id. at 1 ("Beneficial uses of produced water include crop irrigation, livestock watering, streamflow augmentation, and municipal and industrial uses. Produced water also can be placed in aquifer storage for future use."). See generally Produced Water Management Practices and Applicable Regulations, WYO.OIL \& GAS CONSERVATION COMM'N, http:/www.netl.doe.gov/research/coal/crosscutting/pwmis/fed-state-regulations/wyoming (last accessed Sept. 11, 2015); see also What Are Beneficial Uses?, PRODUCED WATER TREATMENT \& BENEFICIAL USE INFO. CENTER, http://aqwatec.mines.edu/produced_water/intro/what/index.htm (last accessed Sept. 11, 2015).

111. See generally Oil and Gas; Hydraulic Fracturing on Federal and Indian Lands; Final Rule, 80 Fed. Reg. 16,128 (March 26, 2015) (to be codified at 43 C.F.R. pt. 3160) [hereinafter Hydraulic Fracturing Final Rule].

112. U.S. DEP'T. OF INTERIOR, supra note 67 , at 29.

113. Id. at 31 .

114. Id. at 33 .

115. See INSTRUCTION MEMORANDUM, DEP'T OF INTERIOR 2 (2012), http://www.blm.gov/pgdata/etc/medialib/b/m/wy/resources/efoia/IMs/2012.Par.59729.File.dat/wy2012007.pdf. In 2011, the BLM "strongly discouraged" open pits and warned that they "should be considered to contain potentially hazardous wastes harmful to human health." Id. The term "hazardous substance" is defined in the Hazardous Waste Operations and Emergency Response regulations, 29 C.F.R. § 1910.120 (2014). Even under the proposed BLM fracking rule, the use of open pits would still be allowed.

116. Natural Gas Extraction - Hydraulic Fracturing, U.S. ENVTL PROTECTION AGENCY, http://www2.epa.gov/hydraulicfracturing (last updated Oct. 4, 2014).

117. Fact Sheet - Offsite Commercial Disposal, U.S. DEP'T OF ENERGY, http://www.netl,doe.gov/research/coal/crosscutting/pwmis/tech-desc/offsite.

118. See id. I bbl (oil barrel) equals 42 U.S. gallons. 
will not hold the water quantity injected. ${ }^{119}$ The second most popular method of disposal is offsite trucking, or hauling the produced water to another site to discharge into a reinjection facility, usually a large geologic formation, but this method is very expensive. ${ }^{120}$ Next is the discharge of produced water for land application (agriculture), which is a relatively inexpensive method and meets beneficial use requirements in certain states. ${ }^{121}$ Finally, produced water is sometimes discharged into open pits and closed tanks for storage; open pits are lined aboveground pools regulated by the BLM for oil and gas leases on federal and Indian lands. ${ }^{122}$

Despite clear warnings from the BLM on the dangers of open pits to wildlife and livestock, ${ }^{123}$ discharges of produced water, rather than underground injection, are commonplace on the Wind River Reservation and in Wyoming in general. For example, Wyoming's Department of Environmental Quality administrator, John Wagner, stated that produced water discharges occur "all over the state and not just on the reservation," and that Wyoming has "several hundred" open discharge sites. ${ }^{124}$ In 2014 , the state had over 35,000 producing oil and gas wells. ${ }^{125}$ The latest estimates show six hundred oil and gas discharge sites throughout the state. ${ }^{126}$ In the Powder River Basin, which occupies parts of Wyoming and Montana, over eight thousand acres of land are irrigated with produced water. ${ }^{127}$

In short, the "beneficial uses," originally construed in the 1980 s under RCRA and the CWA in a relatively new oil and gas E\&P program, have blossomed into a pollution disposal industry that greatly exceeds the limits for environmentally safe waste management. According to a report by Argonne Laboratory, produced water creation in the United States had reached

119. See RICK MCCURDY, UNDERGROUND INJECTION WELLS FOR PRODUCED WATER DisPOSAL, CHESAPEAKE ENERGY CORPORATION 1, 32-33, http://www2.epa.gov/sites/production/files /documents/21_McCurdy_-_UIC_Disposal_508.pdf.

120. U.S. ENVTL. PROTECTION AGENCY, supra note 116.

121. Id.

122. 43 C.F.R. $\$ 3162.5-1$ (2014); 25 C.F.R. \$ 225.4 (2014); Instruction Memorandum (WY-2012-007): Management of Oil and Gas Exploration and Production Pits, U.S. DEP'T OF INTERIOR 3 (Nov. 15, 2011), http://www.blm.gov/pgdata/etc/medialib/blm/wy/resources/efoia/IMs/2012.Par.59729 .File.dat/wy2012-007.pdf.

123. U.S. DEP'T OF INTERIOR, supra note 122, at 2. In 2011 the BLM "strongly discouraged" open pits and warned they "should be considered to contain potentially hazardous wastes harmful to human health." Id. The term "hazardous substance" is defined in the Hazardous Waste Operations and Emergency Response regulations. See 29 C.F.R. § 1910.120.

124. Irina Zhorov, Surface Water Discharge Used in Oil Recovery Common Throughout Wyoming, WYO. PUB. MEDIA (Nov. 21, 2012), http://wyomingpublicmedia.com/post/surfacedischarge-water-used-oil-recovery-common-throughout-wyoming.

125. Wyoming Oil and Gas: Facts and Figures 2015 Edition, PETROLEUM ASS'N OF WYO., http://www.pawyo.org/facts-figuers.pdf (last accessed Sept. 11, 2015).

126. Pedro Ramirez, Jr., Oil Field Produced Water Discharges Into Wetlands in Wyoming, U.S. FISH \& WILDLIFE SERVICE 1 (Aug. 2002), http://www.fws.gov/mountain-prairie /contaminants/papers/r6718c02.pdf.

127. NAT'L RESEARCH COUNCIL, MANAGEMENT AND EFFECTS OF COALBED METHANE Produced Water IN THE Western United States 37 (2010). 
$20,995,174,000$ bbl per year by $2007 .{ }^{128}$ In Wyoming alone, oil and gas production generated $2,355,671,186 \mathrm{bbl}$ of produced water in $2007,{ }^{129}$ demonstrating the oil and gas industry's astounding growth since RCRA's and the CWA's regulatory mechanisms were initiated. This increase has resulted in a waste disposal problem affecting many sectors of society, but notably Native American lands.

\section{The Wind River Nations and The Federal Government}

It is difficult to discuss the livestock loophole and tribes in general because every tribe's circumstances are different. ${ }^{130}$ For tribes that do not incorporate farming or ranching, the impacts of the livestock loophole might be felt only peripherally, if they share a reservation with a ranching tribe, or if they are located downstream or downwind of a ranching tribe that has accepted produced water. For those that do engage in ranching, for subsistence or for profit, the impacts of the livestock loophole might be more immediately felt.

In addition, it is hard to make general observations about tribal relationships with the federal government and the corresponding trust relationship because the basis for the trust and the strength of the federal government's duty vary depending on the source of the trust relationship and the extent to which tribes have ceded authority to the federal government by treaty. Some tribes still live on or near their native lands, which are not owned by the federal government. ${ }^{131}$ Other tribes have been removed, relocated to reservations, and seen their reservations broken up into trust allotments, owned by the federal government but occupied by the tribal members. ${ }^{132}$ Still other tribes reside on a portion of their native lands, but through a succession of treaties, the tribes have conveyed the underlying title to their reservations to the federal government in exchange for monetary payments or for protection from hostile neighbors. ${ }^{133}$ This is the case with the Shoshone of the Wind River Reservation. ${ }^{134}$ Finally, some tribes, like the Arapaho of the Wind River Reservation, were removed to reservations

128. ARgonne Nat'L LaB., Produced WATER Volumes and Management PRACTICES IN THE UNITED STATES 30 (Sept. 2009), http:/www.circleofblue.org/waternews/wpcontent/uploads/2010/09/ANL_EVS_R09_produced_water_volume_report_2437.pdf.

129. Id. at $4 \overline{4}$.

130. On the Wind River Reservation, one of several Arapaho business ventures is a cattle ranch. See Location, NORTHERN ARAPAHO TRIBE, http://www.northemarapaho.com/location (last accessed Sept. 17, 2015); ARAPAHO RANCH, http://www.arapahoranch.com/ (last accessed Sept. 17, 2015). The Navajo Nation also relies extensively on sheep ranching for subsistence. See Diego James Robles, Navajo Ranching in the Chuska Mountains, HIGH COUNTRY NEws (Oct. 10, 2014), https:// www.hcn.org/articles/Navajo-ranching-New-Mexico-Chuska. 373,377 (1921).

131. The Choctaw tribe of Mississippi is one example. See Winton v. Amos, 255 U.S.

132. The Quinault Nation, of Washington, is one example. See United States v. Mitchell, 463 U.S. 206, 207-08 (1983).

133. Shoshone Tribe of Indians of Wind River Reservation in Wyoming v. United States, 299 U.S. 476, 485-86 (1937).

134. Id. 
that are not part of their historical homelands and reside there as a result of a forced relocation effort on the part of the federal government, executed primarily through Congressional enactments. ${ }^{135}$ A complete history of the Shoshone and Arapaho tribes goes beyond the scope of this Article; however, some historical perspective is necessary to see how the federal trust relationship developed, as discussed in Part V, below.

In the early $1800 \mathrm{~s}$, the Arapaho Nation occupied the High Plains of Colorado, near the Platte and the Arkansas Rivers. ${ }^{136}$ The Arapaho forcibly resisted the federal government's attempts to relocate them onto a reservation until 1878 , when they succumbed to starvation and massive population loss. ${ }^{137}$ They gradually migrated north and west, until they reached the Wind River Reservation, under military escort, in approximately $1888 .{ }^{138}$ At that point, the Shoshone, who were traditionally enemies of the Arapaho, had already moved onto the reservation. ${ }^{139}$ For the next twenty-eight years, under the command of the federal government, the Arapaho attempted to resettle on the reservation alongside the Shoshone. ${ }^{140}$ However, these efforts were met with some hostility from the Shoshone, whose treaty with the federal government guaranteed them undisturbed occupancy of the reservation in $1868 .{ }^{141}$

This reservation, now called the Wind River Reservation, was formally created in 1868 through the Fort Bridger Treaty. ${ }^{142}$ In the Treaty, the United States agreed to set aside land in what is now central Wyoming, in an area rich with mineral deposits but lacking in water and arable soil. ${ }^{143}$ The Treaty also included reserved water rights. ${ }^{144}$ All of the pledges contained and implied in the Treaty, which are discussed in further detail in Part V below, reflected the central purpose of the Treaty and of the Reservation, which was to force the Shoshone to transition from nomadic buffalo hunters to members of an agrarian, sedentary communities. ${ }^{145}$ Moreover, it provided that the lands within the reservation's boundaries "shall be . . . set apart for the absolute and undisturbed use and occupation of the Shoshonee [sic] . . . and for such other friendly tribes."146

135. Id. at $494-95$.

136. ANTON TREUER, ET. AL., INDIAN NATIONS OF NORTH AMERICA 152(2010); Robert Retherford, A Local Development Agreement on Access to Sacred Lands, 75 U. COLO. L. REV, 963, 967 (2004).

137. 299 U.S. at 490 .

138. Id. at 487 .

139. Id.

140. Id.

141. Id. at $488-89$.

142. 1868 Treaty of Fort Bridger, art. II., Feb. 24, 1869, 15 Stat. 673.

143. 299 U.S. at 486; see also Walter Rusinek, A Preview of Coming Attractions? Wyoming v. United States and the Reserved Rights Doctrine, 17 ECOL. L.Q. 355, 380 (1990).

144. See Winters v. United States, 207 U.S. 564, 577 (1908) (holding that American Indian tribes have a senior right to water on their lands, in order to continue their self-sufficiency and survival).

145. United States v. Shoshone Tribe, 304 U.S. 111, 118 (1938).

146. 299 U.S. at 490. 
Finally, the Treaty provided that "Congress shall provide for protecting the rights of the Indian settlers in these improvements."147

Eventually, the federal government was able to broker an arrangement whereby both tribes could occupy the reservation, albeit in different areas, and despite the fact that this arrangement was a direct breach of the Fort Bridger Treaty. ${ }^{148}$ The tribes agreed to settle in different areas, with the Shoshone centered in the northwest portion and the Arapaho in the southeast. Both tribes are currently "recognized" by the federal government, which carries great significance, but for the purposes of this Article, it means that they fall within the mineral leasing and waste disposals regimes applicable to "Indian Country."149

Although it has undergone changes since 1868, the Wind River Reservation is the now the third largest reservation in the nation and home to 3,900 enrolled Eastern Shoshone and approximately 8,600 enrolled Northern Arapaho people. ${ }^{150}$ The two tribes operate independently in government affairs, but they jointly regulate their shared natural resource interests. ${ }^{151}$ They also have historically collaborated together in the Shoshone and Arapahoe Joint Business Council. ${ }^{152}$ Both tribes profit from leasing tribal lands to oil and gas operations, and the Northern Arapaho in particular sought produced water from neighboring oil and gas operations to use for their cattle. ${ }^{153}$ The Northern Arapaho tribe is ideally situated to accept produced water, given that the Wind River Reservation is surrounded by fracking operations, or potential areas of fracking development, on almost every side. ${ }^{154}$ The source of the federal government's obligation to regulate those produced water discharges, at present and in the future, is discussed below.

\section{The Federal Trust Doctrine, RCRA, and the CWA}

Thus far, this Article has described the health effects and environmentally unsound consequences of the livestock loophole. It has also introduced the Wind

147. Id. (emphasis added).

148. Id.

149. Indian Tribal Entities Within the Contiguous 48 States Recognized and Eligible to Receive Services from the United States Bureau of Indian Affairs, 80 Fed. Reg. 1942, 1943 (Jan. 14, 2015).

150. Rusinek, supra note 143 , at 378 .

151. The Northem Arapaho and Eastem Shoshone Tribes of the Wind River Reservation Laws, INTERMOUNTAIN OIL AND GAS BMP PROJECT, http:/www.oilandgasbmps.org/laws /tribal/windriver.php (last accessed Sept. 11, 2015).

152. Trevor Graff, Northern Arapahoe Dissolves Joint Business Council, CASPER STAR TRIBUNE (Sept. 10, 2014), http://trib.com/news/state-and-regional/northern-arapaho-tribe-dissolves-jointbusiness-council/article_c8c834d9-b940-5ebd-8792-cdd18450855e.html; see also In re General Adjudication of Rights to Use Water in the Bighom River System, 753 P.2d 76, 84 (Wyo. 1988), rev'd on other grounds, Vaughn v. State, 962 P.2d 149 (Wyo. 1998) (Big Horn).

153. See Conoco, Inc. v. Shoshone \& Arapahoe Tribes, 569 F. Supp. 801,801 (1983).

154. To the northeast, the Powder River Basin region currently contains more than 26,000 coal bed methane wells. 
River Reservation and explained the history of the Wind River Nations' relationship with the United States government. This Part introduces and examines the Federal Trust Doctrine ${ }^{155}$ that protects Indian Country and its resources with regard to environmental regulation and is inextricably linked to the history of the federal government's dealings with tribes, such as those of the Wind River Reservation. This Part then examines RCRA and the CWA in light of this Doctrine.

\section{A. Background of the Federal Trust Doctrine}

As a matter of federal law, a trust relationship exists between the federal government and native tribes residing on lands within "Indian Country," which is a jurisdictional term including reservations, dependent Indian communities, and trust lands. ${ }^{156}$ The relationship is complex and sui generis because tribes are governmental entities, but they possess limited sovereignty, and they exist within another nation that claims almost absolute sovereignty over them. ${ }^{157}$

This system of dual sovereignty, a form of legal pluralism, arose out of the European conquest of North American tribes. ${ }^{158}$ During that conquest, colonizing settlers and colonial governments signed treaties with native nations to establish a foothold on the North American continent; however, when native populations declined to accede to their demands in negotiation, the colonial powers seized what they needed by force. ${ }^{159}$

The foundational principles for the Federal Trust Doctrine emerged in the Northwest Ordinance of 1787 , ratified in $1789,{ }^{160}$ which stated:

The utmost good faith shall always be observed toward the Indians; their lands and property shall never be taken from them without their consent; and in their property, rights and liberty they shall never be invaded or disturbed, unless in just and lawful wars authorized by Congress; but laws founded in justice and humanity

155. In 2015, there were 66,492 oil and gas wells in Wyoming, Over 1.I Million Active Oil and Gas Wells in the US, FRACTRACKER ALLIANCE (Mar. 4, 2014), http://www.fractracker.org/2014/03/active-gas-and-oil-wells-in-us/, and approximately 3,500 wells in the Freemont and Hot Springs counties, where the Wind River Reservation resides, Oil and Gas Wells in the US (2015), FRACTRACKER ALLIANCE hitp://maps.fractracker.org/latest?webmap= 49102e45079445fabdb9b5c0679d96ee (last accessed Sept. 17, 2015).

156. 18 U.S.C. $\S 1151$ (2012).

157. Richard L. Barnes, From John Marshall to Thurgood Marshall: A Tale of Innovation and Evolution in Federal Indian Law Jurisdiction, 57 LOY. L. REV. 435, 436 (2011); see also Cherokee Nation v. Georgia, 30 U.S. 1, 2 (1831).

158. N. BRUCE DUTHU, SHADOW NATIONS: TRIBAL SOVEREIGNTY AND THE LiMITS OF Legal PluRalism (2014).

159. See Nell Jessup Newton, Indian Claims in the Courts of the Conqueror, 41 AM. U. L. REV. 753, 754 (1992); see e.g., Johnson and Graham's Lessee v. M'Intosh, 21 U.S. 543 (1823); Cherokee Nation v. Georgia, 30 U.S. 1, 4 (1831).

160. An Act to Provide for the Government of the Territory Northwest of the River Ohio, 1 Stat. 50, 53 (1789). 
shall, from time to time, be made, for preventing wrongs being done to them, and for preserving peace and friendship with them. ${ }^{161}$

The intent of Congress in the Northwest Ordinance was clear: the United States government would treat native peoples fairly and with respect, and it was expected that laws would be promulgated only to thwart injustice and to preserve peace. ${ }^{162}$ Over time, the sentiments put forward by the document lost favor, giving way to more nefarious dealings with the tribes on the part of the United States government and resulting in an imbalance of power and the seizure of Indian private property through the Treaty system. ${ }^{163}$

Around the same time as the Northwest Ordinance of 1789 , the United States government effectively sealed a permanent place for native tribes under Congress's domain in what is known as the Indian Commerce Clause of Article I of the Constitution. ${ }^{164}$ That provision states only that Congress has power to "regulate commerce . . . with the Indian Tribes," but the Supreme Court has interpreted this clause to authorize congressional plenary power over Native American affairs. ${ }^{165}$

The modern Federal Trust Doctrine originated in the early nineteenth century during the United States government's attempt to assimilate Native Americans into mainstream American culture by seizing tribal lands and then holding those lands in small parcels, or allotments, in trust for the tribes. ${ }^{166}$ The origins of the modern Doctrine stemmed from a series of cases penned by then Chief Justice John Marshall, commonly known as the "Marshall Trilogy."167

First, in Johnson v. McIntosh, the Court established the Doctrine of Discovery, under which the federal government could seize native lands by force or by treaty and would hold title to those lands subject to a native right of occupancy. ${ }^{168}$ The second case, Cherokee Nation v. Georgia, presented the issue of whether the Cherokee Nation was a foreign state with sovereign authority to exclude non-members from its borders. ${ }^{169}$ The Court defined Indian Nations as

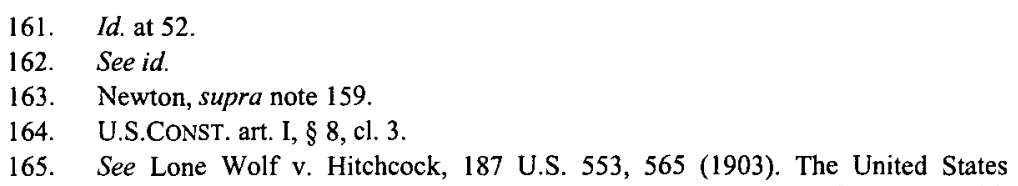
Constitution's Commerce Clause provides, "Congress shall have the Power. . to regulate Commerce with

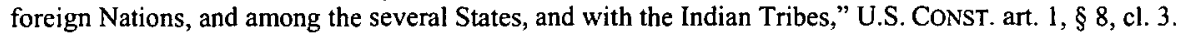
This now encompasses Congress's "plenary power" over Native American affairs, giving Congress the legal right to ignore treaties with Tribes when passing legislation related to Tribes. The Court opined, "when treaties were entered into between the United States and a tribe of Indians it was never doubted that the power to abrogate existed in Congress, and that in a contingency such a power might be availed of from considerations of governmental policy." Lone Wolf, 187 U.S. at 566.

166. General Allotment (Dawes) Act, ch. 119, § 1, 24 Stat. 388 (1887) (codified as amended at 25 U.S.C. $\$ \S 331-334,339,341-342,348-349,354,381$ (1983)).

167. Philip J. Prygoski, From Marshall to Marshall: The Supreme Court's Changing Stance on Tribal Sovereignty, 12 COMPLEAT LAWYER 14, 15 (1995).

168. Johnson v. McIntosh, 21 U.S. 543, 592 (1823).

169. Cherokee Nation v. Georgia, 30 U.S. 1, 2 (1831). 
sui generis and as "domestic dependent nations ... in a state of pupilage . . . [like] a ward to a guardian." "170 The next year, the Court held in Worcester $v$. Georgia that Indian Tribes have sovereign rights over their lands and that states could not infringe, legislatively or otherwise, upon tribal sovereignty. ${ }^{171}$ In Worcester, the Court extended the notion of tribes as sui generis legal entities and held that the United States government had a duty to "protect" the tribes' sovereignty and tribal lands, ${ }^{172}$ which over the decades presented a double-edged sword in terms of tribal self-governance. ${ }^{173}$

It was along this continuum of struggle over power and the limits of sovereignty that the current Federal Trust Doctrine crystallized. From the "plenary power" Congress possessed over "Indian affairs," announced in the early Supreme Court case of United States $v$. Kagama, ${ }^{174}$ grew a corresponding notion that the federal government owed the tribes a duty of protection. ${ }^{175}$ The duty was originally based on the Supreme Court's view that, after almost a century of warfare with the federal government, tribes were "savage," "weak," and "helpless," largely dependent upon the United States for daily food and their very survival. ${ }^{176}$ Because of the power imbalance between the tribes and the federal government, it was the federal government's responsibility to ensure that they did not starve, succumb to disease, or lose any means of livelihood. ${ }^{177}$ In the words of the Supreme Court:

These Indian tribes are the wards of the nation. They are communities dependent on the United States. . . From their very weakness and helplessness, so largely due to the course of dealing of the Federal Government with them and the treaties in which it has been promised, there arises the duty of protection, and with it the power. ${ }^{178}$

The historical power imbalance between the federal government and the native nations adds a heightened duty beyond that of a landlord or other fiduciary. This duty is based on the federal treaties establishing the Federal Trust

170. Id. Justice Marshall used as guidance, the Hopewell Treaty of 1785 , the treaty of origin between the U.S. government and the Cherokee Nation. Jeri Beth K. Ezra, Comment, The Trust Doctrine: A Source of Protection for Native American Sacred Sites, 38 CATHOLIC U. L. REV. 709 (1989).

171. Worcester v. Georgia, 31 U.S. 515 (1832).

172. Id.

173. Following the Marshall Trilogy, the Court broadened the U.S. Government's relationship to Tribes to a decidedly patemalistic model. See United States v. Kagama, 118 U.S. 375 (1886). In 1980 the Court finally overruled antiquated decisions that gave Congress and the President unrestrained power over the Tribes. See United States v. Sioux Nation, 448 U.S. 371 (1980).

174. Kagama, 118 U.S. 375 (1886).

175. Mary Christina Wood, Indian Land and the Promise of Native Sovereignty: The Trust Doctrine Revisited, 1994 UTAH L. REV. 1471, 1498.

176. 31 U.S. at 582 (1832).

177. Id:; see Kagama 118 U.S. at 383-84

178. Kagama, 118 U.S. at 383-84. 
relationship, such as the Fort Bridger Treaty establishing the Wind River Reservation.

\section{B. The Modern Federal Trust Doctrine}

The guardian/ward relationship established in Kagama has evolved, not in substance, but in form, into what the Supreme Court refers to as a "trust" relationship between the federal government, as trustee, and the tribes, as beneficiaries. ${ }^{179}$ Although scholars and the Court debate the exact source of the federal trust responsibility, they agree that since Congress possesses plenary power to legislate regarding "all things Indian," the federal government has "concomitant fiduciary duties" to implement and enforce that legislation in a manner that protects tribal property and respects tribal political integrity. ${ }^{180}$

Current Supreme Court jurisprudence recognizes that a trust relationship can form out of a treaty, statute, federal common law, or any combination thereof. ${ }^{181}$ In essence, tribes must "identify a substantive source of law that establishes specific fiduciary or other duties, and allege that the government has failed faithfully to perform those duties." 182 If a treaty or statute is the identified source, courts apply the canons of construction requiring them to interpret provisions or terms broadly, in a manner that favors the tribes. ${ }^{183}$

When the trust relationship arises from a statute, the Supreme Court has held that the federal government must administer that statute in a manner similar to the fiduciary duty of a trustee if there is a sovereign relationship, even if the statute does not expressly include the term "trust." 184

In light of these principles, it is evident that the United States may have a fiduciary duty toward tribes even if the treaty or statute in question is silent with respect to whether a fiduciary duty exists. Several federal courts have also recognized that the Federal Trust Doctrine imposes a special duty on environmental agencies to regulate in a manner that "is in the best interests" of tribes. ${ }^{185}$ According to these decisions, the Doctrine requires agencies to consider the best interest of the tribes when making decisions about how to administer environmental laws in Indian Country. ${ }^{186}$

179. Nell Jessup Newton, Enforcing the Federal-Indian Trust Relationship After Mitchell, 31 CATH. U.L. REV. 635, 635 (1982)

180. Id. at 643-44.

181. United States v. Navajo Nation, 537 U.S. 488 (2003); United States v. Mitchell, 463 U.S. 206, 225 (2003); see also Newton, supra note 179, at 638.

182. 537 U.S. at 490 .

183. Id.

184. White Mtn. Apache Tribe v. Bracker, 537 U.S. 465, 475 (2003); Mitchell, 463 U.S at 225; Navajo Tribe of Indians v. United States, 624 F.2d 981, 987 (1980).

185. Woods Petroleum Corp. v. Dep't of Interior, 47 F.3d 1032, 1043 (10th Cir. 1995) (citing Jicarilla Apache Tribe v. Supron Energy Corp., 728 F.2d 1555, 1563 (10th Cir. 1984)); Burlington Resources Oil \& Gas. Co. v. U.S. Dep't of Interior, 21 F. Supp. 2d 1, 5 (D.D.C. 1998).

186. Judith V. Royster, Mineral Development in Indian Country: The Evolution of Tribal Control Over Mineral Resources, 29 TULSA L.J. 54 1, 568 (1994); Mary Christina Wood, Fulfilling 
For the Wind River tribes, the language of the Fort Bridger Treaty of $1868^{187}$ provides the basis for the trust relationship with the federal government. ${ }^{188}$ This treaty provided that the reservation lands would be set aside for the "absolute and undisturbed" use of the Shoshone, and subsequently, the Arapaho peoples. ${ }^{189}$ As noted above in Part IV, the treaty also stated that the federal government should "protect[] the rights of the Indian settlers." 190 This treaty established the foundation of the federal trust relationship between the federal government and the tribes residing on the Wind River Reservation, ${ }^{191}$ which continues to guide the federal government's environmental stewardship responsibilities, as discussed below.

\section{The EPA's Current Policies Regarding Its Federal Trust Responsibilities}

The Supreme Court has stated that the United States' duty towards Indian tribes is "a moral obligation of the highest responsibility and trust," to be carried out under "the most exacting fiduciary standards," and exercised with "every moral and equitable consideration to discharge its trust with good faith and fairness." 192 The courts have placed a binding responsibility on the Executive Branch, and by extension all federal agencies and departments that work with Native Americans, including the EPA, to conduct their dealings with tribes in accordance with their positions as fiduciaries for all recognized tribes. ${ }^{193}$

The EPA's own stated policies comport with these cases. In 1984, under President Reagan, the EPA adopted a formal Indian policy entitled "EPA Policy

the Executive's Trust Responsibility Toward Native Nations on Environmental Issues: A Partial Critique of the Clinton Administration's Promises and Performance, 25 ENVTL. L. 733 (1995).

187. The first Treaty of Fort Bridger was ratified in 1863. See Legal Analysis of the Wind River Reservation Boundary, U.S. ENVLT. PROTECTION AGENCY 3 (2013), http://www2.epa.gov /sites/production/files/2013-12/documents/attachment2capabilitystatement.pdf.

188. Treaty of Fort Bridger, supra note 142.

189. Id.

190. Id.

191. United States v. Mitchell, 463 U.S. 206, 225 (1983). The foundation of the trust relationship between the federal government and the Arapaho is the federally sanctioned, and forced, Arapaho occupancy of the Wind River Reservation, combined with a federal statute authorizing their resettlement, passed in 1927. See Shoshone Indian Tribe of Wind River Reservation v. United States, 364 F.3d 1339, 1343 (2004).

192. Seminole Nation v. United States, 316 U.S. 286, 296 (1942); United States v. Payne, 264 U.S. 446, 448 (1924).

193. In United States v. Creek Nation, 295 U.S. 103, 109 (1935), the Supreme Court based its decision on the federal trust doctrine to award the tribe money damages for mismanaged lands by a U.S. agency, holding that the United States' power to control and manage tribal lands "was not absolute" and was "subject to limitations inhering in such a guardianship and to pertinent constitutional restrictions," and that the Executive cannot "give the tribal lands to others, or . . . appropriate them to its own purposes." This created a strict standard of due care and behavior toward the Tribes. See also Nance v. EPA, 645 F.2d 701, 711 (9th Cir. 1981) (acknowledging that all agencies fall under the federal trust doctrine); U.S. ENVTL. PROTECTION AGENCY, IMPLEMENTING INSTITUTIONAL CONTROLS IN INDIAN COUNTRY 44 (Nov. 2013), http://www.epa.gov/oerrpage/superfund/policy/ic/guide/lCs_in_Indian Country_FINAL.pdf [hereinafter InStITUTIONAL CONTROLS]; U.S. ENVTL. PROTECTION. AĞENCY, WORKING EFFECTIVELY WITH TRIBAL GOVERNMENTS 47 (July 1998), http://www.epa.gov/Indian/wetg /training/EPA/common/data/docs/WETGResourceGuide.pdf. 
for the Administration of Environmental Programs on Indian Reservations," which was "[r]eaffirmed" by the EPA in January 2014. ${ }^{194}$ The current Administrator of the EPA, Gina McCarthy, was very clear in articulating the EPA's commitment to act as a fiduciary in "all aspects of the EPA's day-to-day functions" in Indian Country:

[T]he EPA reiterates its recognition ... [that] it has a unique legal relationship with tribal governments based on the Constitution, treaties, statutes, executive orders and court decisions. The EPA ... acknowledges the federal government's trust responsibility to tribes. The EPA works ... with Tribes . . . to protect the land, air and water in Indian Country . . . and . . . human health and to safeguard the environment in Indian Country. ${ }^{195}$

Within these parameters, the EPA specifically states that it "directly implements federal environmental statutes in Indian country," and its policies "clarify how it interacts with tribal governments and considers tribal interests in carrying out its programs to protect human health and the environment."196

Furthermore, President Obama stated in his 2013 Executive Order Establishing the White House Council on Native American Affairs, "This order establishes a national policy to ensure that the Federal Government engages in a true and lasting government-to-government relationship with federally recognized tribes in a more coordinated and effective manner, including by better carrying out its trust responsibilities. This policy is established as a means of promoting and sustaining prosperous and resilient tribal communities. Greater engagement and meaningful consultation with tribes is of paramount importance in developing any policies affecting tribal nations." 197 Interior Secretary Sally Jewell summarized the federal trust responsibility contained within that Order as follows: "This Order . . . demonstrates our continuing commitment to upholding the important federal trust responsibility for Indian Country." 198 Thus, there currently appears to be a clear and unwavering commitment on the part of the Executive Branch to protect the interests of Native Americans, and this

194. Memorandum from Gina McCarthy, Administrator, Envtl. Protection Agency, to All Employees, Envtl. Protection Agency (Jan 9, 2014), http://www.epa.gov/tribalportal/basicinfo/1984indian-policy-reaffirmation-memo-09JAN 14.pdf. The EPA has singularly included Indian Nations in its Federal permitting framework due to the fiduciary duty placed on the Executive Branch, and has developed an extensive consultation process. See U.S. ENVTL. PROTECTION. AGENCY, EPA POLICY ON CONSULTATION AND COORDINATION WITH INDIAN TRIBES (May 4, 2011), http://www.epa.gov/indian/pdf /cons-and-coord-with-indian-tribes-policy.pdf.

195. McCarthy, supra note 194.

196. INSTITUTIONAL CONTROLS, supra note 193.

197. Establishing the White House Council on Native American Affairs, 78 Fed. Reg. 39,539, 39,539 (June 26, 2013).

198. Secretary Jewell Issues Secretarial Order Affirming American Indian Trust Responsibilities, U.S DEP'T OF INTERIOR (Aug. 20, 2014), https://www.doi.gov/news/pressreleases /secretary-jewell-issues-secretarial-order-affirming-american-indian-trust-responsibilities. 
commitment extends to all federal agencies and to the statutes and regulations they administer.

Prior case law further supports this executive commitment to protecting the interests of tribes. In Northern Cheyenne v. Hodel, for example, the court's interpretation of the fiduciary duty requires the United States government to consult, cooperate, and coordinate with tribes, and requires an analysis of "harm to the environment, including the cultural, social, and economic cost to the Tribe" when a legal challenge arises affecting the public interest. ${ }^{199}$ In Morton $v$. Mancari, the Supreme Court acknowledged the constitutional underpinnings of fiduciary protection and the concomitant power to implement the "unique obligation" of the United States toward Tribes. ${ }^{200}$ In short, the EPA has a fiduciary role to protect the interests of Indian Tribes when it administers statutes, including RCRA and the CWA, based on has a solid foundation in treaties, case law, and executive statements. The next two subsections, Parts V.E and V.F illustrate how the EPA is failing to meet the requirements of the Trust Doctrine under RCRA and the CWA.

\section{The Federal Trust and the Livestock Loophole Under RCRA}

The purpose of RCRA is to "protect human health and the environment" from improper hazardous waste disposal, "to conserve valuable material and energy resources," to eliminate "open dumping," and to "assur[e] that hazardous waste management practices are conducted" in a safe manner. ${ }^{201}$ However, the EPA's RCRA regulations, and specifically the E\&P exemption for "special wastes," violate both the spirit of RCRA and the Federal Trust duty to tribes, implicit in RCRA.

The EPA readily admits to the antiquated nature of RCRA's "special wastes" provision. As discussed in Part III.A, this provision is an element of the livestock loophole that exempts oil and gas wastes from regulation, and it thus has a direct effect on environmental health and water quality. ${ }^{202}$ In the EPA's own words:

These wastes typically are generated in large volumes and, at the time [they were implemented], were believed to possess less risk to human health and the environment than the wastes being identified for regulation as hazardous waste. ${ }^{203}$

This comment makes it evident that the EPA is aware of the problem of excessive toxins in produced water and suggests that the agency's assessment of

199. Northern Cheyenne Tribe v. Hodel, 12 Indian L. Rep. 3065 (D. Mont. 1985).

200. Morton v. Mancari, 417 U.S. 345, 552 (1973).

201. 42 U.S.C. $\$ 6902$ (a) (2012).

202. OIL AND GAS EXEMPTION, supra note 63, at 5 .

203. Special Wastes, U.S. ENVT'L. ProT. AGENCY, http://www.epa.gov/osw/nonhaz /industrial/special/ (site last updated on Nov. 15, 2012) (emphasis added). 
the risk to livestock, human, wildlife, agricultural, and environmental health has increased over time. ${ }^{204}$ Despite this awareness, and even in light of wellpublicized scientific and news reports of the toxic effects of chemicals found in produced water, the EPA continues to allow discharges of hazardous wastes in Indian Country under the livestock loophole. ${ }^{205}$

Blue Legs v. United States Bureau of Indian Affairs helps shed light on the EPA's fiduciary responsibility under RCRA to protect the health of tribal members and the wildlife found on tribal lands. ${ }^{206}$ Two members of the Oglala Sioux nation sued the EPA, the Bureau of Indian Affairs (BIA), and the Indian Health Service (IHS), claiming that more than fourteen garbage dumps on their reservation violated RCRA. ${ }^{207}$ The majority of sites were located near "houses, schools, and streams or springs" and were unfenced, lacked sanitary trenches, were uncovered, and were unsupervised; all site locations had experienced fires. ${ }^{208}$ Testing of "water samples from the sites showed significant contamination ... including organisms capable of caus[ing] disease in wildlife and frequently in humans." 209 The court also found that "[c]hildren, pets and others [could] easily come in contact with the sites given the . . condition of the dumps" 210 and that the sites represented a danger to nearby residents even if they did not wander near them. ${ }^{211}$

The court addressed the Federal Trust duty specifically, noting that Congress intended for RCRA to "remedy national problems caused by hazardous waste and solid waste disposal"212 and to "regulate the disposal of discarded

204. Glicksman, supra note 72 , at 42 . In addition to the Pavillion, Wyoming case discussed in this Article, there have been other documented cases of produced water contamination that threatens human and animal health. For example, an underground pipe leaked over one million gallons of produced water onto lands in the Fort Berthoud Indian Reservation North Dakota, part of the Bakken Shale Fields. The EPA has not provided any studies to demonstrate the two-mile long waste stream's effects on the waters it contaminated. North Dakota Briny Wastewater Spill Questions Still Unanswered a Month Later, INDIAN COUNTRY TODAY (July 15, 2014), http://indiancountrytodaymedianetwork,com $/ 2014 / 08 / 25 /$ north-dakota-briny-wastewater-spill-questions-still-unanswered-month-later- 156579 . Four states that have heavy fracking activity have been found to contain widespread produced water contamination in water-wells: Texas, Pennsylvania, Ohio, and West Virginia. Kevin Begos, Water Pollution From Drilling Confirmed in at Least Four States, Casting Doubt on Safety of Boom, HUFFINGTON POST (Jan. 23, 2014), http://www.huffingtonpost.com/2014/01/06/water-pollution-drilling $\mathrm{n} \_4548561 . \mathrm{html}$. High levels of toxic fracking chemicals have been found in Central California aquifers, including thallium and arsenic. Hollin Kretzman, Documents Reveal Billions of Gallons of Oil Industry Wastewater Illegally Injected Into Central California Aquifers, CTR. FOR BIOLOGICAL DIVERSITY (Oct. 6, 2014), http://www.biologicaldiversity.org/news/press_releases/2014/fracking-10-06-2014.html.

205. Lena Groeger, What the Frack Is That Water?, ProPuBLICA (Mar. 7, 2012), http:// www.propublica.org/special/what-the-frack-is-in-that-water.

206. Blue Legs v. U.S. Bureau of Indian Affairs, 867 F.2d 1094, 1099 (8th Cir. 1989) (citing 42 U.S.C. $\$ 6903(28)$ (2012)) ("Throughout the RCRA, [t] the term 'solid waste management" means the systematic administration of activities which provide for the collection, source separation, storage, transportation, transfer, processing, treatment, and disposal of solid waste.").

$\begin{array}{ll}207 . & I d . \text { at } 1099 . \\ 208 . & I d . \text { at } 1096 . \\ 209 . & I d . \\ 210 . & I d . \\ 211 . & I d . \\ 212 . & I d . \text { at } 1096 .\end{array}$


materials on reservations," adding that all citizens are permitted to bring compliance suits against any person, ${ }^{213}$ agency, the United States government, or instrumentality. ${ }^{214}$ In its conclusion, the court discussed the responsibility of two Executive agencies (the BIA and IHS) to clean up the dumps in accordance with "the general trust relationship between these agencies and the Tribe," and it noted that a trust duty can be inferred even without specific reference in the statute $^{215}$ : "If . . . the Government means that the document has to say in specific terms that a trust or fiduciary relationship exists or is created, we cannot agree. The existence vel non of the relationship can be inferred from the nature of the transaction or activity." 216 To buttress this argument, the court included a congressional report on proposed legislation that "eliminates the last remaining loophole in environmental law, that of unregulated land disposal of discarded materials and hazardous wastes," and "specific examples of harm to be avoided, including Indian children playing in dumps on reservations." ${ }^{217}$ In the final analysis, the court in Blue Legs assigned responsibility to the tribes, and not the EPA, to operate and regulate the reservation solid waste dumps because the court found tribes held inherent sovereign authority to do so. ${ }^{218}$ The Blue Legs decision highlights the fiduciary duty on the part of executive agencies like the EPA toward native tribes, particularly as the "special wastes" exemption does not comport with current legal decisions that aim to protect human health on tribal lands.

\section{E. The Federal Trust and the CWA's Livestock Loophole}

The CWA is a sweeping statute: federal agencies, departments, or instrumentalities of the federal government that have jurisdiction over any property or facility that is engaged in any activity that results in a discharge or runoff of pollutants must comply with it. ${ }^{219}$ The CWA also serves as a regulatory

213. Id. at 1097 (citing 42 U.S.C. $\$ 6903(15)(2012)$ ).

214. Id. (citing 42 U.S.C. $\S 6972(\mathrm{a})(\mathrm{l})(\mathrm{A})$ ) (emphasis added) ("Person" includes municipalities, and municipalities include "an Indian tribe or authorized tribal organization."); id. (citing 42 U.S.C. $\S 6903(13)(\mathrm{A}))$.

215. Id. at 1100 .

216. Id. (emphasis added).

217. H.R. Rep. No. 94-1491, 94th Cong., 2d Sess. pt. 1, at 4 (1976) (House Report), reprinted in 1976 U.S.C.C.A.N. $6238,6241-42$.

218. Blue Legs, 867 F.2d at 1101 .

219. 33 U.S.C. $\$ 1323$ (a) (2012). The Clean Water Act was passed in 1972 and enacted in 1977, and is the primary law regulating disposal of toxic substances into "waters of the United States." Id. The intent of Congress in passing the law was to "restore and maintain the chemical, physical, and biological integrity of the Nation's waters." Id. $\S 1251$ (a). To accomplish that objective, the CWA called for a water quality standard nationwide by 1983 that provides for "the protection and propagation of fish, shellfish, and wildlife, and ... for recreation in and on the water," and the elimination of pollution discharges into navigable waters by $1985 . I d$. $\S 1251(a)(1)$. 
tool for Indian tribes to maintain surface water quality for waters on tribal lands. ${ }^{220}$

As mentioned above, the CWA does not specifically provide a Federal Trust duty per se. However, due to the vast scope of the statute, it encompasses waters that run through reservations such as the Wind River Reservation. As this section will explain, the CWA gives the EPA sole jurisdiction to implement the CWA for certain tribes. Thus the Trust Doctrine extends to the government's relationship and dealings with these tribes, and indeed all tribes, under the CWA.

Originally, the CWA did not assign regulatory authority over tribal lands, but left the matter unsettled. ${ }^{221}$ Severe pollution concerns prompted tribes to successfully lobby for a 1987 statutory amendment authorizing the Tribes As States (TAS) program, which acknowledges tribal sovereignty by allowing tribes to set their own surface water quality standards under the CWA if they meet required federal benchmarks as set out by the EPA. ${ }^{222}$ It also gives qualified tribes the ability to administer water quality certifications for federal permits and licenses for activities that cause discharges into navigable waters. ${ }^{223}$ Many tribes, such as the Wind River tribes, do not currently have TAS status; thus, they cannot directly regulate tribal water quality under the CWA. ${ }^{224}$ The EPA is the sole regulator and enforcer of the CWA, and it is authorized to set water quality standards nationwide, including on reservations where the tribes do not have

220. Collective water rights on reservations are governed by the reserved rights doctrine, which requires that the federal government, upon reserving land for native people, reserve adequate water under the state's appropriative system, to sustain them and to support the purposes for which the reservation was created. Winters v. United States, 207 U.S. 564,577 (1908). Under the reserved rights doctrine, native people resettled on reservations are entitled to sufficient water to allow them to continue any traditional subsistence activities and engage in new subsistence patterns pursuant to treaties. United States v. Winans, 198 U.S. 371 (1905). The reserved rights doctrine establishes both the existence and the scope of reserved water rights, see Amy Allison, Extending Winters to Water Quality: Allowing Groundwater for Hatcheries, 77 WASH. L. REV. 1 193, 1217 (2002), as well as a minimum guarantee that "all of the waters" flowing through a reservation remain "undiminished in quantity and undeteriorated in quality," Sean M. Hanlon, A Non-Indian Entity Is Polluting Indian Waters: "Water" Your Rights to the Waters, and "Water" Ya Gonna Do About It?, 69 MONT. L. REV. 173, 204 (2008).

221. Robin Kundis Craig, Borders and Discharges: Regulation of Tribal Activities Under the Clean Water Act in States with NPDES Permitting Authority, 16 UCLA J. ENVTL. L. \& POL'Y 1,8 (1998).

222. 33 U.S.C. $§ 1343$ (c) (2012). The "Treatment as a State" Program was technically renamed in 1994, and is now referred to as "the program approval process or treatment in the same manner as a state." See Authorization for Tribes to Administer Water Quality Standards Program, U.S. ENVTL. PROTECTION AGENCY, http://water.epa.gov/scitech/swguidance/standards/wqslibrary/auth.cfm (last updated July 8, 2013). However, it is still colloquially known as "TAS status" on EPA documents and on its website. See id.; see also Strategy for Reviewing Tribal Eligibility Applications to Administer EPA Regulatory Programs, U.S. ENVTL. PROTECTION AGENCY, (Jan. 23, 2008), http://water.epa.gov/scitech /swguidance/standards/wqslibrary/upload/strategy-for-reviewing-applications-for-tas-01-23-08.pdf.

223. 33 U.S.C. \$ 1377(a); see also Montana v. EPA, 137 F.3d 1135, 1139 (9th Cir. 1998) (determining that tribes do not have the authority to regulate non-Indians' hunting and fishing activities on fee lands within the Crow reservation).

224. Indian Tribal Approvals, U.S. ENVTL. PROTECTION AGENCY, http://water.epa.gov /scitech/swguidance/standards/wqslibrary/approvtable.cfm (site last updated Jan. 15, 2014). 
TAS status. ${ }^{225}$ For example, water quality regulation for the Wind River tribes is carried out under the EPA Regional Office, which works in collaboration with the Wind River Environmental Quality Commission to implement the CWA's Section 106 monitoring, assessment, and regulation programs. ${ }^{226}$

Agencies are tasked with balancing economic interests in carrying out policy, oftentimes to the detriment of human health and the environment. The EPA should take into account various stakeholders' needs while regulating water quality issues, and in the case of its Federal Trust duty to tribes, the agency must consider the subsistence patterns and special status of tribes. For example, the Penobscot Tribe in Maine addressed the EPA's discharge policy as a Federal Trust issue. ${ }^{227}$ The tribe is located thirty-five miles downstream from a paper mill that discharges dioxin, a toxic chemical byproduct of the papermaking process, into the Penobscot River. ${ }^{228}$ Surveys of the river showed high levels of the chemical, which prompted authorities to issue a warning to not consume more than twelve meals containing fish per year. ${ }^{229}$ While the EPA responded by issuing a new National Pollutant Discharge Elimination System (NPDES) permit to the paper mill that had very stringent dioxin limits, through the consultation process, the tribe further urged the EPA to "take into account its Trust Responsibility in writing the [paper mill's] permit." 230 The tribe appealed for a permit that would "restore for our members as quickly as possible their right to fish in the Penobscot River for their individual sustenance in a manner that poses no risk to their health... . Until EPA can assure that our members will be able to fully and safely exercise our fishing rights, we believe that the EPA is violating its trust responsibility and the Clean Water Act."231

The EPA said it had met its trust obligation by exposing the tribe to only "acceptable" and "reasonable" health risks. ${ }^{232}$ "The tribe disagreed with the policy and stated the EPA failed to meet its Trust duty, as it didn't protect waters

225. Kevin H. Kono, The Trust Doctrine and the Clean Water Act: The Environmental Protection Agency's Duty to Enforce Tribal Water Quality Standards Against Upstream Polluters, 80 OR. L. REV. 677, 714 (2001) (citing 33 U.S.C. $\$ 1313($ c)(4) (2012)). See generally, Browner, 97 F.3d at 422. The court noted the CWA's inconsistent statutory construction with regard to TAS status and the EPA's role, saying "Congress' intent[ion] in excluding [the TAS section] . . . is unclear and ambiguous." Id. The Court upheld the Tribe's right to set stricter water quality limits than the federal government through the Tribe's "residual sovereign powers that already guarantee the powers enumerated" in the TAS section of the CWA. Id.

226. See Scott Clow, EPA Region VIII Tribal Water Quality Programs, Clean Water Act Section 106 Success Stories, UTE MOUNTAIN TRIBE 20 (Nov. 2005), http://www .utemountainuteenvironmental.org/umep/assets/File/Water/Success_Stories_2005.pdf .

227. Darren J. Ranco, Power and Knowledge in Regulating American Indian Environments: The Trust Responsibility, Limited Sovereignty, and the Problem of Difference, in ENIVRONMENTAL CRISIS OR CRISIS OF EPISTEMOLOGY?: WORKING FOR SUSTAINABLE KNOWLEDGE AND ENVIRONMENTAL JUSTICE 122 (Bunyan Bryant, ed. 2011).

228. See id.

229. Id.

230. Id. at 113 .

231. Id. at 114 (emphasis added).

232. Id. 
that the sub-population depended upon for subsistence."233 The EPA responded, through procedural posturing, that the agency had met its responsibility to the tribe. ${ }^{234}$ As exemplified in this case, it is the EPA's responsibility to protect human health through environmental regulation, using both the Federal Trust Doctrine and the requirements contained in the CWA.

\section{F. Trade Secrets and the Federal Trust}

In the twenty-five years since RCRA and the CWA livestock loophole components were established, changes in fracking techniques have resulted in the addition of more than 632 chemical ingredients into injected water. ${ }^{235}$ Setting effluent limits requires knowledge of the chemicals and compounds that exist in produced water; however, the oil and gas industry ardently works to conceal this information. ${ }^{236}$ States set their own requirements for disclosure of chemicals, and many states have "trade secrets" provisions that allow companies to keep a proprietary formula's ingredients secret from regulators and the public. ${ }^{237}$ For example, in one study, only $14 \%$ of the 944 proprietary chemical products included the ingredients for scientific review. ${ }^{238}$ For 407 of the products, less than $1 \%$ of the total ingredient composition was available for review. ${ }^{239}$ Produced water discharges often include known carcinogens such as benzene, xylene, and glycol. ${ }^{240}$

Trade secrets that affect Indian Country fall under the BLM's regulatory power. ${ }^{241}$ In 2012, the BLM proposed a new rule that would require disclosure of chemicals used in the fracking process thirty days before drilling commenced. ${ }^{242}$ Oil and gas industry lobbyists were successful in petitioning the BLM to amend the proposed rule so that operators could bypass this restriction if they asserted the existence of a trade secret by affidavit. ${ }^{243}$ The BLM issued its

233. Id. at 116 . (emphasis added)

234. Id. at 118 .

235. Theo Colbom et al., Natural Gas Operations from a Public Health Perspective, 17 HUM. ECOLOGICAL RISK ASSESSMENT 1039, 1045 (2011). This does not include oil and coal bed methane operations.

236. Ben Elgin et al., Fracking Secrets by the Thousands Keep U.S. Clueless on Wells, BLOOMBERG (Nov. 30, 2012), http://www.bloomberg.com/news/2012-11-30/frack-secrets-by-thousandskeep-u-s-clueless-on-wells.html.

237. Cora Currier, ALEC and ExxonMobil Push Loopholes in Fracking Chemical Disclosure Rules, PRo PUBLICA (Apr. 24, 2012), http://www.propublica.org/article/alec-and-exxonmobilpush-loopholes-in-fracking-chemical-disclosure-rules.

238. Colborn et al., supra note 235 , at 1045.

239. Id.

240. Michael Goldman, Drilling into Hydraulic Fracturing and Shale Gas Development: A Texas and Federal Environmental Perspective, 19 TEX. WESLEYAN L. REV. 185, 247 (2012).

241. 43 C.F.R. pt. 3160 (2014).

242. Oil and Gas: Hydraulic Fracturing on Federal and Indian Lands: Supplemental Notice of Proposed Rulemaking and Request for Comment, 78 Fed. Reg. 31,636, 31,637 (May 24, 2013). 243. Id. 
final rule on March 26, 2015, preserving this and other protections for E\&P operators. ${ }^{244}$ The BLM also retained the post-production affidavit requirement ${ }^{245}$ and the authority to ask for additional facts to determine whether information is a trade secret, ${ }^{246}$ and it changed disclosure requirements to allow the generic name of chemical compounds, as the generic name would "not constitute a trade secret because it is or should be public, and the operator can still withhold the specific chemical identity."247 In its justification for eliminating trade secrets from the required disclosure provisions, the BLM stated that it "was sufficient to assure that the vast majority of operators will assert only good faith claims for trade secret protection." 248 Despite receiving extensive comments requesting that operators should be required to disclose the contents of fracking fluids before operations commence, the EPA acknowledged that it made "no revisions to the rule . . as a result of these comments." 249

The stated reason for not requiring complete disclosure of fracking chemical formulations is that the new rule requires operators to disclose chemicals used to the independent website "FracFocus" after fracking is completed. ${ }^{250}$ Yet FracFocus has been the subject of many complaints because it can be difficult for users to navigate and has demonstrated a pattern of "crashing" and otherwise failing to function in a predictable manner. ${ }^{251}$

All agencies, including the BLM, are required to comply with the CWA. ${ }^{252}$ Thus, despite changes in the final fracking rule, withholding chemical trade secrets that are discharged into navigable waters violates the CWA's requirement of control and abatement of water pollution through water quality standards, as there is no possible way for the BLM to satisfy those standards without knowing the exact chemical makeup of drilling fluids.

Moreover, the EPA, consistent with its trust responsibility, is required to incorporate the "latest scientific knowledge" in its water quality criteria and in setting effluent limits when implementing and enforcing the CWA in Indian

244. Hydraulic Fracturing Final Rule, supra note 111. The Executive Summary states: "The final rule fulfills the goals of the initial proposed rules: To ensure that wells are properly constructed to protect water supplies, to make certain that the fluids that flow back to the surface as a result of hydraulic fracturing operations are managed in an environmentally responsible way, and to provide public disclosure of the chemicals used in hydraulic fracturing fluids." $I d$. at 16,128 . Requirements for oil and gas operations that were modified in the Final Rule are at 43 C.F.R. $\$ 3162.3-1$ and Onshore Oil and Gas Orders 1,2 and 7. Id. at 16,129 .

245. Id. at 16,130 .

246. Id.

247. Id. at 16,172 . The BLM states that generic chemical compounds must be disclosed to the EPA under the Toxic Substances Control Act. Id. (citing U.S. ENVTL. PROTECTION AGENCY, INSTRUCTION MANUAL FOR REPORTING UNDER THE TSCA § 5 NEW CHEMICALS PROGRAM 33 (2003)).

248. Id. at 16,171 .

249. Id. at 16,149 .

250. Id. at 16,133 .

251. Id. at 16,168 .

252. 33 U.S.C. $\$ 1311$ (2012). 
Country, ${ }^{253}$ so full disclosure of chemical compounds in produced water is critical. The amount of information concealed by trade secrets hinders the ability of the EPA to set effluent limits and monitoring plans for those chemicals. This results in contamination of water supplies in Indian Country and elsewhere that may affect human health through direct exposure and livestock poisoning. The end result is that trade secrets interfere with both the EPA's and the BLM's ability to serve as trustees in regulating the hazards of produced water disposal in Indian Country.

VI. Moving Forward: Recommendations on How to Eliminate the Livestock Loophole from Existing Laws

As an initial matter, any recommendation that would completely close the livestock loophole would fall short of respecting tribal sovereignty if it did not provide a meaningful role for tribal governments. Given that this Article analyzes the federal components only, the following options explore the manner by which the federal government could satisfy its obligations under the Federal Trust Doctrine. But, this discussion acknowledges at the outset that taking the following measures would only fix half of the problem.

\section{A. The EPA Should Revise RCRA's Exempt Status Trigger to Include Produced Water}

The EPA has decided not to regulate E\&P wastes such as produced water under Subtitle $C$ of RCRA. ${ }^{254}$ This is because the EPA has adopted the position that exempt status for wastes is not determined only by whether the material is hazardous or toxic, but by how stringently such wastes are regulated by previously existing state or federal requirements, and by "the economic impacts" of any regulation on oil and gas exploration and development operations. ${ }^{255}$ The EPA explains,

[S]ome exempt E\&P wastes might be harmful to human health and the environment, and many non-exempt wastes might not be as harmful. The following simple rule of thumb can be used to determine if an E\&P waste is exempt or non-exempt from RCRA Subtitle $C$ regulations:

- Has the waste come from down-hole, i.e., was it brought to the surface during oil and gas E\&P operations?

253. Id. $\S 1314(\mathrm{a})(1)$; see also Robert Erickson, Protecting Tribal Waters: The Clean Water Act Takes over Where Tribal Sovereignty Leaves Off, 15 TUL. ENVTL. L.J. 425, 438 (2001).

254. George C. Coggins, et al., Oil and Gas Wastes and the Bentsen Amendment, 2 PUB. NAT. RESOURCES L. § 20:20 (2d ed. 2015).

255. Regulatory Determination for Oil \& Gas and Geothermal Exploration, Development and Production Wastes, 53 Fed. Reg. 25,446-01, 25,454 (July 6, 1988). 
- Has the waste otherwise been generated by contact with the oil and gas production stream during the removal of produced water or other contaminants from the product? ${ }^{256}$

In other words, even if the waste is harmful to human health and the environment, simply by virtue of the fact that it is a waste generated by the oil and gas industry, it is free from rigorous regulatory measures under RCRA. However, this policy contravenes RCRA's general purpose of protecting "health and the environment." ${ }^{257}$ Toxic compounds from oil and gas operations must be included in all RCRA regulatory processes, including Subtitle C, in order to maintain adequate environmental safeguards.

This statutory structure creates a system under which tribes are basically dependent on the EPA to implement RCRA in a manner that protects the tribe from land-based disposal of toxic materials. However, because of the current exclusion of produced water from RCRA's Subtitle C definition, there are only minimal permitting standards that apply to produced water discharges in Indian Country-equivalent to those required for landfills containing nonhazardous waste. ${ }^{258}$ In brief, under RCRA, there are dual forces operating against tribes: a lack of meaningful authority to restrict produced water from being dumped on tribal lands and a regulatory classification of produced water that imposes minimal disposal standards. Thus, the EPA should regulate produced water under Subtitle C of RCRA.

\section{B. The CWA's Livestock and Wildlife Subcategory Should Exclude Produced Water}

The CWA's Subpart E, "Agricultural and Wildlife Water Use Subcategory," 259 should be amended to prohibit classifying produced water as a beneficial use for livestock, agriculture, and wildlife purposes, and produced water should be regulated under the CWA's NPDES program. Despite arid conditions and the shortage of water in the West, produced water, with its numerous toxic chemicals, is not an adequate substitute for water. The EPA would serve tribes and the general population well if it modified its definition of "good enough quality" for produced water to be used for livestock, agriculture,

256. Id.

257. E.g., 42 U.S.C. $\$ 6902$ (a) (2012). In matters of self-governance, RCRA, unlike other major environmental statutes such as the Clean Air Act and the Clean Water Act, does not contain a congressional recognition of tribes as the regulatory equivalent of states. See id. $\$ \S 6901-6992 k$. Arguably, tribes could develop their own environmental regulations as sovereign governments, and many have. But, because RCRA does not affirmatively delegate authority to them, or recognize their inherent sovereign power as it does under other environmental statutes, there is no mechanism for federally recognized tribes to obtain federal funds to issue permits or otherwise regulate waste disposal on tribal lands.

258. See 42 U.S.C. $\$ \S 6941-6949$ a (2012).

259. 40 C.F.R. $\S 435.50-.52$ (2015). 
and wildlife $\mathrm{e}^{260}$ to reflect more stringent regulations. This is especially true given the recent studies that have determined produced water to be a clear factor in livestock and wildlife poisoning. ${ }^{261}$

Since the Wind River tribes have not received TAS status and thus cannot set their own effluent limits, waters within their reservation have been improperly managed by the EPA, ${ }^{262}$ which relies on science that oftentimes is "several decades old." 263 The EPA has the sole responsibility to regulate produced water discharges into navigable streams and waterbodies on the Wind River Reservation through NPDES permits; ${ }^{264}$ thus, consistent with its federal trust obligations, the EPA must regulate produced water discharges more stringently for tribes lacking TAS status, which it can do in several ways.

\section{The Federal Government Should Set Effluent Limits for Produced Water Contents for Non-TAS Tribes}

Effluent limits are a critical tool to stem water pollution and protect the quality of water that is consumed by humans and animals alike. The EPA sets national oil and grease effluent limitations for produced water under RCRA, ${ }^{265}$ but it does not address other components, compounds, or chemicals that are common in produced water and pose direct harm to humans and animals that consume them or come into contact with them. The result is that the EPA has effectively delegated the responsibility to states to regulate chemicals they deem hazardous, or to tribes if they have TAS status. ${ }^{266}$ But for tribes that lack TAS status, the EPA has breached its fiduciary responsibility to protect their water quality by failing to regulate the contents of produced water ${ }^{267}$ as the EPA is required by the Clean Water Act to regularly update effluent limitations. ${ }^{268}$

Following the analysis in Montana v. United States, in which the court held that "water quality management serves the purposes of protecting public health

260. 40 C.F.R. $\S 435.51(\mathrm{c})$.
261. Kendall Gurule, Produced Water, FraKWIRE (June 25, 2013),
WY-0033740, US. Statement of Basis-Marathon Oil Company Steamboat Butte Field 2, Permit No. /files/documents/FINALWY-0033740MarathonSteamboatButteSOBmod.pdf.

263. M. F. Raisbeck et al., Water Quality Criteria for Wyoming Livestock and Wildlife Final Report at 1, WYOMING DEP'T OF ENVTL. QUALITY \& WYOMING DEP'T OF GAME AND FISH (2011), http://www.uwyo.edw/owp/_files/project24finalreport.pdf.

264. 33 U.S.C. $\$ 1377($ e) (2012).

265. See 40 C.F.R. $\S 435.52(a)(2)$.

266. 020-080-002 WYO. CODE R. app. H § (b)(i) (LexisNexis 2012) ("In no case shall any produced water discharge contain toxic materials in concentrations or combinations which are toxic to human, animal or aquatic life.").

267. Colborn et al., supra note 235 , at 1097.

268. 33 U.S.C. $\$ 1314(a)(6)$ (2012) ("The Administrator shall, within three months after December 27, 1977, and annually thereafter, for purposes of section 1311(h) of this title publish and revise as appropriate information identifying each water quality standard in effect under this chapter or State law, the specific pollutants associated with such water quality standard, and the particular waters to which such water quality standard applies." (emphasis added)). 
and safety,"269 courts should call upon the EPA to "utilize its discretionary power to promulgate and enforce stringent water quality standards for reservation waters even where the applicable tribe may not qualify for TAS status but is otherwise governed by an established tribal government."270 For tribes that have not received TAS status, and thus cannot regulate their tribal waterways, lakes, and ponds, an additional rule that would prohibit the discharge of produced water would help satisfy the EPA's fiduciary obligations to Indian tribes.

\section{If the EPA Continues to Administer the CWA in Indian Country, Effective Monitoring, Inspections, and Scientific Studies Must Be Required}

Effective water quality management begins with monitoring, inspecting, and collecting samples of water at facilities holding an NPDES permit and reporting the findings in order to determine appropriate effluent limits for NPDES permit holders. ${ }^{271}$ The EPA should adopt an adaptive management program in Indian Country similar to what other federal agencies have done with wildlife resources on public lands outside Indian Country. ${ }^{272}$ This would ensure that the EPA, consistent with its trust responsibility to Wind River tribes, would oversee monitoring so it is done in a technologically advanced, comprehensive, and thorough manner to record pollution rates on the reservation. As yet, there is little evidence that this is occurring. When monitoring and oversight does not happen, the resulting problem is two-fold: monitoring requirements within permits allow fracking to occur long before chemical testing or maintenance flushing, ${ }^{273}$ and water quality data on oil and gas lease sites remain undeveloped. ${ }^{274}$

Moreover, up-to-date investigations and studies are two additional critical tools for determining the effects of produced water salinity on livestock, wildlife, and plants on the Wind River Reservation. To illustrate, the United States Bureau of Reclamation reported that livestock can tolerate lesser quality water than humans, but salinity and specific ions can harm animals. ${ }^{275}$ Produced water used

269. Kono, supra note 225 , at 715.

270. Id. at 708 .

271. See generally, U.S. ENvTL. PROTECTION AGENCY, NPDES COMPLIANCE INSPECTION MANUAL (2004), http://www2.epa.gov/sites/production/files/2013-09/documents /npdesinspect_0.pdf.; see also 40 C.F.R. $§ 122.44$ (2014).

272. Hillary M. Hoffmann, Climate Change and the Decline of the Federal Range: Is Adaptive Management the Solution?, 15 VT. J. ENVTL. L. 262, 271 (2013).

273. Kristen Stade, Don't Drink the Fracking Fluids!, PEER (July 9, 2013), http:// www.peer.org/news/news-releases/2013/07/09/don't-drink-the-fracking-fluids!.

274. In 2005, it was reported that the Wind River Environmental Quality Commission (WREQC) had established "[fifty] surface water quality monitoring sites throughout the reservation" where sampling on water quality chemistry and bacteria samples and field data, occurred monthly and quarterly. Clow, supra note 226. The Wind River Environmental Quality Commission also monitors watersand water quality criteria for certain projects. It is financially subsidized by the U.S. government under the CWA Section 106 Water Pollution and Control Grant Program.

275. U.S. DEP'T OF INTERIOR, supra note 67, at 27. Upper levels for toxic substances in produced water have been found by the National Academy of Sciences. $I d$. at $28.82 \%$ of wells tested for 
for livestock watering, wildlife watering, and habitat can be "more saline than seawater," according to a report from the United States Department of Energy. ${ }^{276}$ Another government study linked high salinity and chemical levels in produced water to vegetation die-off, soil salinization, soil erosion, surface and groundwater contamination, and toxicity in plants. ${ }^{277}$

Data produced by these types of studies prove to be invaluable tools for regulatory safeguards; however, Congress, agencies tasked with regulating oil and gas production wastes, and the EPA have largely ignored such studies. ${ }^{278}$ Disregarding or defunding ${ }^{279}$ these preliminary segments of effluent level regulation prevents setting accurate benchmarks that protect water quality, and this results in a failure to adequately protect the water quality in Indian Country. A first feasible step would be for Congress to take into account these and other studies and to properly fund effluent regulation compliance for navigable waters on tribal lands to protect tribes from toxins, including those on the Wind River Reservation.

\section{E. The CWA's Spill Prevention, Control, and Countermeasure (SPCC) Rule Should be Enforced to Emphasize Tribal Protections}

The CWA has in place spill prevention and planning requirements under the Spill Prevention, Control, and Countermeasure (SPCC) rule. ${ }^{280}$ This rule requires certain oil and gas fracking operations-those that have 1,320 gallons or more of oil storage that could reasonably be expected to discharge oil into U.S. navigable waters - to prepare and implement a plan that describes how they will "control, contain, clean up, and mitigate the effects of any oil discharges that occur."281

According to EPA officials, nearly all oil and gas rigs exceed the 1,320 gallon limit, and most well sites are subject to the SPCC rule during drilling if

livestock use that contained produced water failed to meet the least conservative criteria for health. Id. at 64. A 2011 scientific multidisciplinary report stated, "While animals can, and often do, subsist upon lessthan-perfect drinking water such as that produced by oil and gas development ("produced water"), there are tradeoffs with health and productivity. Raisbeck, supra note 267 , at 1 .

276. CLARK \& VEIL, supra note 2, at 14.

277. Environmental Impacts Associated with Disposal of Saline Water Produced During Petroleum Production - Osage-Skiatook Petroleum Environmental Research Project, U.S. GEOLOGICAL SURVEY, http://toxics.usgs.gov/sites/produced_water/ph20_page2.html (last updated Aug. 4, 2015).

278. Id. In order to meet the need for more scientific data, the United States Geological Survey in 2001 initiated a multi-party and multi-disciplinary investigation to determine the effects produced water has on the surface environment.

279. Timothy Cama, 30 GOP Senators Sponsor Bill to Stop EPA's Water Rule, THE HILL (June 19, 2014), http://thehill.com/policy/energy-environment/209997-30-gop-senators-sponsor-bill -to-stop-epas-water-rule.

280. 40 C.F.R. $\S 112.3$ (2003)

281. Id. $\S 112.1$. 
they are near navigable waters. ${ }^{282}$ The EPA implements this rule, rather than delegating its authority to the states. ${ }^{283}$ Yet, due to the lack of a registration and submission requirement, oil and gas facilities are not required to report SPCC information to the EPA, so the EPA is not even aware of the "universe of SPCCregulated facilities." 284 The result was that in fiscal year 2011 alone inspectors found noncompliance with the SPCC rule at 105 out of 120 oil and gas well sites in the EPA's Region 8, located in Wyoming, Colorado, Montana, Utah, North Dakota, and South Dakota. ${ }^{285}$ Likewise, the EPA, U.S. Fish and Wildlife Service (FWS), states, and tribes participated in a survey of open pits of produced water that killed or harmed birds and found that "[n]on-compliance with SPCC requirements was more pervasive than anticipated." 286 To protect tribes and fulfill its federal trust responsibility, the EPA must require registration for all wells and submission of SPCC requirements to the agency on a regular basis.

\section{F. The Beneficial Use Requirement Must Be Revised to Reflect Federal or Tribal Control}

As stated above in Part III, the livestock loophole allows produced water to be discharged if it is beneficially used for agriculture and livestock watering. ${ }^{287}$ Produced water utilized in this manner circumvents the historical purpose of the beneficial use doctrine, which was to benefit the appropriator in a way that does not harm other users. ${ }^{288}$ The livestock loophole, therefore, subverts the beneficial use doctrine by allowing uses that are harmful to humans, livestock, wildlife, and the environment. Prolonged and sustained consumption of toxic chemicals by living organisms cannot be classified as "beneficial" under any common sense meaning of the term.

Moreover, states such as Wyoming, rather than the EPA, determine the manner and scope of produced water discharge plans for beneficial uses. ${ }^{289}$ The purpose of delegating decisions regarding produced water for beneficial use to states may be to assist industry in costly efforts to dispose of toxins, ${ }^{290}$ and also

282. U.S. GOV'T ACCOUNTABILITY OFFICE, GAO-12-874, UNCONVENTIONAL OIL AND Gas Dev.: Key EnVtl. AND Public HeAlth ReQuirements 27 (2012).

283. Id. at 20 .

284. Id. at 27-28.

285. Id. at 28

286. Id. at 124 .

(2015).

287. Applicability; Description of the Beneficial Use Subcategory, 40 C.F.R. $\S 435.50$ 1997) (en banc).

288. Okanogan Wilderness League, Inc. v. Town of Twisp, 947 P.2d 732, 738 (Wash.

289. See In re Gen. Adjudication of All Rights to Use Water in the Bighorn River System, 835 P.2d 299 (Wyo. 1992) (nullifying the tribe's control over reserved water rights and state waters on the reservation, giving the control to administer these rights to the State Engineer, and leaving the Tribal Water Code's administration of beneficial uses in question.

290. See Beneficial Use Portal: Web Portal Resources Covering Beneficial Use of Industrial Byproducts, http://www.beneficialuseportal.org (last visited Feb. 11, 2015) ("Beneficial use can reduce or eliminate disposal costs and it has a highly positive impact on our dwindling landfill capacity."). 
to relieve states like Wyoming from having to take costly measures to contain hazardous wastes. This, in turn, leads to excessive pollution in and near waterways that affects water and wildlife on reservations.

For example, in one recent proposed rule, the EPA declared that toxic substances such as coal combustion residuals (CCR) should not be classified as having a "beneficial use" when that use is a questionable activity such as "the filling up of old quarries and gravel pits."291 The EPA solicited comments for possible standards based on a risk assessment, taking into consideration "the CCRs character and composition, their leaching potential under the range of conditions under which CCRs will be managed, and the context in which the CCRs will be applied, such as location, volume, rate of application, and proximity to water." 292 The EPA then defined beneficial use with regard to CCRs by listing criteria "to ensure legitimate beneficial uses can be identified and enforcement action can be taken against inappropriate uses." 293 Finally, and most critically, the proposed rule notes that "EPA would consider application of CCRs for agriculture uses not to be a legitimate beneficial use if they occurred at constituent levels or loading rates greater than EPA's biosolids regulations allow."294 The EPA would help fulfill its fiduciary responsibility to the Wind River tribes, and other similarly situated Tribes, by applying these same principles to produced water regulation and policy restructuring and relieving the states of this responsibility.

\section{G. Trade Secrets Protections Preventing Disclosure of Produced Water Content Must Be Eliminated in the Interest of Native Health}

Setting effluent limits requires knowledge of the chemicals that exist in produced water; the oil and gas industry, however, has successfully fought to withhold that information. ${ }^{295}$ As discussed in Part V, ${ }^{296}$ oil and gas industry lobbyists were successful in amending the BLM's proposed fracking rule that would have required disclosure of the operators' fracking chemicals thirty days before a well operation commenced. The final rule absorbed the proposals, so disclosure of chemical compounds is required only after drilling operations have

291. Hazardous and Solid Waste Management System; Identification and Listing of Special Wastes; Disposal of Coal Combustion Residuals from Electric Utilities, 75 Fed. Reg. 35,128, 35,161 (June 21, 2010).

292. Id.

293. Id. at $35,162-63$ ("The material used must provide a functional benefit. For example, CCRs in concrete must increase the durability of concrete; CCRs as a soil amendment adjusts the $\mathrm{pH}$ of soil to promote plant growthFalseThe material substitutes for the use of virgin material ... Where relevant product specifications or regulatory standards are available, the materials meet those specifications and where such specifications or standards have not been established, they are not being used in excess quantities ...").

294. Id. at 35,163 (emphasis added).

295. Elgin et al., supra note 236.

296. Hydraulic Fracturing Final Rule, supra note 111 , at 16,130. 
commenced, ${ }^{297}$ allowing industry to bypass restrictions on toxins by asserting trade secrets. Such a lack of disclosure makes it impossible for the EPA to not only regularly set appropriate effluent limits required by the CWA, ${ }^{298}$ but also to protect the public, wildlife, and livestock from toxic substances in Native American waters. The Federal Trust Doctrine requires these disclosures for the benefit of recognized and unrecognized tribes alike.

\title{
H. The EPA's Role as Both Trustee and Regulator Presents a Conflict of Interest, so Another Agency Should Assume the Role of Trustee
}

With respect to produced water discharges in Indian Country, for tribes lacking CWA TAS status, such as the Wind River tribes, the EPA acts as the water quality regulator and enforcer, as non-TAS tribes cannot set their own water quality criteria. In addition, it must act as a trustee for the tribes under the standards established by the Supreme Court. This places EPA squarely in the midst of a conflict of interest that principles of trust law would prohibit: the trustee essentially sets the standards and then enforces its own compliance with those standards, while the beneficiary lacks any recourse when and if the trustee fails in setting or enforcing reasonable standards.

The EPA has received a fair amount of criticism for ineffective or nonexistent enforcement, even from anonymous workers within the agency. ${ }^{299}$ At best, conflicting policy directives seem to reflect a gap in sound management practices. At worst, special interests and a powerful ranching lobby may be driving policy that is helpful to only a few stakeholders, and at the same time violating the main principles of the Bridger Treaty and statutory law.

In 2012, the EPA Office of Inspector General submitted an internal report titled, "EPA Must Improve Oversight of State Enforcement," which states:

EPA does not administer a consistent national enforcement program. Despite efforts by the Office of Enforcement and Compliance Assurance (OECA) and the EPA regions to improve state enforcement performance, state enforcement programs frequently do not meet national goals and states do not always take necessary enforcement actions. State enforcement programs are underperforming: EPA data indicate that noncompliance is high and the level of enforcement is low. EPA does not consistently hold states accountable for meeting enforcement standards, has not set clear and consistent national benchmarks, and does not act effectively to curtail weak and inconsistent enforcement by states. ${ }^{300}$

\author{
297. Id. \\ 298. 33 U.S.C. $\$ 1314$ (b) (2012). \\ 299. Shongren, supra note 4. \\ 300. U.S. ENVTL. PRotection Agency, EPA MUST IMProve OVERSight of STATE
} ENFORCEMENT 3 (Dec. 9, 2011), http://www.epa.gov/oig/reports/2012/20111209-12-P-0113.pdf. 
In a recent development in Pavillion, Wyoming, on the Wind River Reservation, the EPA revealed its reticence to protect the Wind River tribes with an appalling policy reversal. As mentioned in Part II, in 2010, the EPA discovered copious amounts of toxic chemicals in the town's drinking water supply and warned residents not to drink, shower, or cook with the tap or well water, or to use fans to disperse the gas fumes while running water out of the tap, in order to avoid an explosion. ${ }^{301}$ After three years of collecting samples and compiling information on contaminants in the groundwater for a draft study to submit to Congress, the EPA halted all work on the study, including peer reviews on the research, with no explanation. ${ }^{302}$ The EPA passed the issue to the state of Wyoming, which plans to work with the oil and gas company responsible for the chemical leak into the town water supply. ${ }^{303}$ Instances like this do not build tribes' confidence in the EPA and reflect a possible trust breach for which the tribes have little recourse except litigation in federal court, a very costly and time consuming process that requires more financial resources than most tribes have.

In an ironic twist, the Justice Department recently initiated a suit against Exxon XTO Energy in Pennsylvania for essentially the same issue: groundwater contamination from produced water. ${ }^{304}$ At the time of this writing, the issue is still being litigated, but the Department of Justice claims Exxon allowed produced water and wastewater to reach water supplies and that they contained "brine, proppant, hydraulic fracturing chemicals, dissolved solids, heavy metals and radionuclides," all of which are dangerous to human and animal health and classified as hazardous wastes under RCRA. Given these inconsistencies, another division of the federal government should be the sole trustee in RCRA and CWA suits originating on Tribal lands that are frequently affected by oil and gas interests. This would provide greater vigor and an additional, more objective perspective in protecting tribes from industry's reach. One option would be the Office of the Special Trustee, which was established by the American Indian Trust Fund Management Reform Act of 1994 to administer trust assets for Native Americans. ${ }^{305}$

Recent scholarship also suggests that Indian tribes are best equipped to both promulgate and administer their own environmental laws. Tribes could work in conjunction with the federal government on compliance and enforcement issues, and citizen suits could serve as an additional enforcement mechanism. ${ }^{306}$

301. Lustgarten, supra note 54.

302. Brinkerhoff \& Wallechinsky, supra note 55

303. Id.

304. Noel Brinkerhoff, Obama Administration Sues Exxon for Polluting Pennsylvania Drinking Water With Toxic Fracking Waste, ALLGov (July 24, 2013), http://www.allgov.com/news /controversies/obama-administration-sues-exxon-for-polluting-pennsylvania-drinking-water-with-toxicfracking-waste- 130724 ?news $=850650$.

305. 25 U.S.C. $\S 4042$ (2012).

306. Kronk Warner, supra note 14, at 73-95. Nine tribes have enacted environmental laws related to the National Environmental Policy Act (NEPA), or general environmental quality laws. Id. at 71 . 
Jurisdiction over polluters within tribal lands is an important matter. In Montana v. United States, the Court prohibited tribes from regulating the activities of nonnatives within tribal boundaries unless discharge permits require the permittee to "consent to tribal jurisdiction," or when tribes regulate actions of non-natives that could adversely affect the health and welfare of the tribe. ${ }^{307}$ Scholars suggest tribal environmental laws could incorporate both exceptions, solving the jurisdictional problem. ${ }^{308}$

In short, and in light of the Obama Administration's commitment to supporting tribal sovereignty, the EPA should restructure the livestock loophole framework.

\section{Conclusion}

The livestock loophole allows oil and gas companies to dispose of toxic oil and gas produced water in Indian Country through regulatory gaps in RCRA and the CWA, and now BLM regulations. Under RCRA, produced water is exempted as a "special waste" and is allowed to be disposed of or stored on land or in underground aquifers; under CWA regulations, produced water can be discharged into navigable waters so long as it is reused to support livestock, wildlife, and agriculture in western arid states under the beneficial use doctrine and if it is of "good enough quality." The toxicity level of produced water is not even considered when determining whether the fluid is exempt under RCRA.

Treaties, case law, and executive policy statements imbue the EPA and BLM with fiduciary responsibilities as the administrators and enforcers of RCRA and the CWA for native people residing in Indian Country. These sources of law also create a federal trust responsibility toward native tribes. Thus, it is the duty of the federal government, through the appropriate branch or agency, to implement and enforce laws and regulations that both benefit and support native people in a way that is beneficial to their health and well-being, including domestic livestock and wildlife. The EPA violated its Federal Trust duty to the Wind River tribes specifically by creating the livestock loophole, and it continues to violate that Trust duty by failing to require complete transparency and disclosure of the contents of toxic chemicals in the produced water discharged on the Wind River Reservation. Moreover, the new BLM rule still allows the oil and gas industry the ability to use toxic chemicals in fracking operations and then claim a proprietary trade secret for those chemicals at a later date, basically sidestepping the regulatory process. The new rule further complicates this issue by giving the BLM full authority to determine what is, or is not, a trade secret, undermining the EPA's regulatory and Trust function in Tribal lands, and resulting in yet another regulatory loophole. 
Over the past half-century, the EPA and BLM's economic balancing test has tipped in favor of industry and away from tribes. These policies created the livestock loophole, and the loophole allows events like what happened on the Wind River Reservation to continue. Although other locations of produced water discharges have not received as much national publicity, the same is true of the EPA's relationship with other tribes throughout the country, particularly those that lack TAS status under the Clean Water Act.

While the final BLM fracking rule does not address all of the problems inherent in the industry, in terms of protecting the tribal environment, it does at least represent the federal government's acknowledgement that it owes a fiduciary obligation to all tribes in Indian Country to regulate fracking on tribal lands. To fully close the livestock loophole, though, the EPA and BLM must do more. 